\title{
Origin of plagiogranites in oceanic complexes: A case study of the Nicoya and Santa Elena terranes, Costa Rica
}

Words: 5609 excluding abstract

\author{
${ }^{1}$ Department of Earth and Environmental Sciences, Korea University, Seoul 136-701, Korea
}

${ }^{2}$ Department of Geosciences, Virginia Tech, 4044 Derring Hall, Blacksburg, Virginia 24061, USA

${ }^{3}$ Korea Basic Science Institute, YangCheong 804-1, Ochang, Cheongwon, Chungbuk 363-883, South

Korea

${ }^{4}$ Escuela Centroamericana de Geología, Universidad de Costa Rica, P.O. Box 214-2060, San José Costa Rica. E-mail: pdenyer@geologia.ucr.ac.cr

* Corresponding author. Tel.: +82-2-3290-3172

E-mail address: whattam@korea.ac.kr 
Abstract

33 The origin of minor leucocratic intrusions known as "plagiogranites" in oceanic 34 complexes dominated by basaltic compositions have been debated in the literature. Here we use 35 well preserved plagiogranites within the contrasting Santa Elena Ophiolite and the Nicoya 36 Complex, NW Costa Rica, to investigate the origin and age of these leucocratic intrusions.

37 Magmatic zircons of plagiogranites of the Santa Elena ophiolite and the Nicoya Complex, yield 38 weighted mean SHRIMP ${ }^{206} \mathrm{~Pb} /{ }^{238} \mathrm{U}$ ages of $125.3 \pm 2.0 \mathrm{Ma}$ and $90.9 \pm 2.0 \mathrm{Ma}$ to $88.5 \pm 2.0 \mathrm{Ma}(n=$ 39 5), respectively. These ages record the main magmatic phases of formation of these intrusions 40 preserved in each complex. Relatively flat, unfractionated chondrite-normalized REE patterns of 41 plagiogranites from both complexes mimic signatures of related mafic rocks, which is consistent

42 with formation via fractional crystallization from a mafic source as opposed to partial melting of 43 a mafic (basalt, amphibolite) protolith. In the case of the Nicoya Complex, modelling suggests 44 that the Nicoya plagiogranites are consistent as $\sim 10-15 \%$ residual liquids after fractional 45 crystallization from its mafic parental source. Trace element systematics of the plagiogranites are 46 consistent with an oceanic arc origin for Santa Elena and a mostly mid-ocean ridge to oceanic47 plateau origin for Nicoya.

49 Keywords: Plagiogranite; trondhjemite, ophiolite; Central America; Costa Rica; Nicoya; Santa Elena 50 


\section{Introduction}

Minor volumes of intrusive, leucocratic, quartz-plagioclase rocks are commonly found in

57 association with high-level gabbros and sheeted dikes of ophiolite complexes, oceanic crust and

58 intra-oceanic crust. Their compositions range from albite granite through trondhjemite and

59 tonalite to diorite and are collectively termed as oceanic plagiogranite (Coleman and Peterman,

60 1975; Coleman and Donato, 1979). Plagiogranite is characterized by very low $\mathrm{K}_{2} \mathrm{O}$ but high

$61 \mathrm{Na}_{2} \mathrm{O}, \mathrm{K} / \mathrm{Rb}, \mathrm{Rb} / \mathrm{Sr}$, and rare earth element (REE) values that render it distinct from many of its

62 continental equivalents.

63 Proposed mechanisms for plagiogranite generation can be grouped into four very

64 different processes: (1) Na metasomatism of K-bearing felsic differentiates (e.g., Gilluly, 1933);

65 (2) immiscibility between felsic and conjugate Fe-enriched basaltic liquids occurring under

66 anhydrous conditions (Dixon and Rutherford, 1979); (3) low-pressure differentiation of

67 subalkaline basaltic magma (e.g., Coleman and Peterman, 1975); and (4) anatexis of amphibolite

68 (Pedersen and Malpas, 1984; Flagler and Spray, 1991) or basaltic/gabbroic crust under hydrous

69 conditions (Sigvaldson, 1974; Koepke et al., 2007). It is generally agreed however, that only

70 mechanisms (3) and (4) represent viable means in which to generate plagiogranite. For example,

71 a purely metasomatic origin is now largely discounted on the basis of collective petrologic and

72 geochemical evidence which demonstrates that plagiogranites originate from a melt rather than

73 by $\mathrm{Na}$ metasomatism of a K-rich felsic precursor (see references below). Another inherent

74 problem with an origin via metasomatism of K-rich felsic rocks is that these rocks are rare in

75 oceanic settings. The possibility of plagiogranite forming by late-stage silicate liquid

76 immiscibility under anhydrous conditions has been suggested by experimental work (Dixon and

77 Rutherford, 1979); however, this has not been verified in the field from ophiolites or in situ 
78 ocean crust. Furthermore, later experimental study demonstrated that immiscibility is not

79 encountered when basaltic systems are crystallized (or melted) in the presence of significant $\mathrm{H}_{2} \mathrm{O}$

80 concentrations (Dixon-Spulber and Rutherford, 1983).

81 Conversely, there is ample evidence to support plagiogranite generation via fractional

82 crystallization or anatexis. Differentiation of a basic magma has been shown as a viable

83 mechanism for example, for the generation of many plagiogranites including those of the Oman

84 (Semail) (Pallister and Knight, 1981; Lippard et al., 1986), Troodos (Coleman and Peterman,

85 1975), Sarikaraman (Turkey) (Floyd et al., 1998) and Oytag (NW China) (Jiang et al., 2008)

86 ophiolites. In these cases, plagiogranite is considered to represent a $\sim 10 \%$ residual liquid formed

87 during the low-pressure crystal fractionation of a subalkaline, low-K tholeiitic magma under

88 hydrous conditions. The feasibility of this mechanism has also been substantiated by

89 experimental work (Dixon-Spulber and Rutherford, 1983). Plagiogranite petrogenesis via

90 anatexis has been established for plagiogranites of the Karmoy ophiolite, Norway (Pedersen and

91 Malpas, 1984) and for the Fournier oceanic fragment of the Canadian Appalachians (Flagler and

92 Spray, 1991) and an anatexis origin has been shown to be valid on the basis of experimental

93 work (France et al., 2010). A fractionation vs. anatexis origin can usually be discriminated on the

94 basis of REE chemistry as we propose in Section 4.3. In addition to providing new high-fidelity,

95 SHRIMP U-Pb zircon ages of plagiogranites from the Nicoya and Santa Elena oceanic fragments

96 of NW Costa Rica, we also provide a new major and trace-element data set for Nicoya and Santa

97 Elena plagiogranites. Finally, our work also presents major and trace-element modeling evidence

98 for the derivation of these plagiogranites by fractionation of a parental basic magma.

99

100 2. Regional geology and tectonic framework 
102 normal oceanic crust and was identified as the first oceanic plateau (Donnelly, 1973), i.e., the

103 Caribbean Large Igneous Plateau (CLIP) (e.g. Hauff et al., 2000a). As such, the Caribbean Plate

104 is mostly comprised of lithosphere of the CLIP oceanic plateau but also embraces subordinate

105 continental fragments along its margin (Dengo, 1985). The thickness of the Caribbean Plate

106 ranges from that of 'normal' oceanic crust to thicknesses about three times that of normal

107 oceanic crust akin to other oceanic plateaus and exhibits a seismic velocity structure analogous to

108 that of the Ontong Java Plateau (Maufrett and Leroy, 1997). West of the Beata Ridge, the

109 Caribbean Plate is about 6-8 km thick whereas it ranges up to $20 \mathrm{~km}$ thick in the region between

110 the central Venezuelan Basin and the western part of the Beata Ridge (Diebold and Driscoll, 111 1999).

112 The western margin of the Caribbean Plate is composed of the Chorotega and Chortis 113 blocks (Dengo, 1985) and the former characterizes an exposed segment of the CLIP mostly 114 buried by Cenozoic lavas of the Central American Volcanic Arc (see recent reviews of Gazel et 115 al., 2015 and Whattam and Stern, 2016). The relation of the northern margin of the Caribbean 116 Plate with the mostly continental Chortis Block is poorly known but is predicted to extend to the 117 south of the Nicoya peninsula in northwestern Costa Rica to the Hess Escarpment (e.g., 118 Meschede and Frisch, 1998; Hoernle et al., 2004; Hoernle and Hauff, 2007). In southern 119 Nicaragua, the southeastern segment of the Chortis Block is comprised of the Siuna Terrane 120 (Rogers et al., 2007) which is composed of deformed oceanic and island arc lavas and intrusives 121 which were accreted to the southern margin of the Chortis Block in the Late Cretaceous 122 (Venable, 1994). 
According to early and mostly still accepted models, the CLIP formed in the eastern

124 Pacific during the Late Cretaceous prior to drifting into its present position over the past 90 m.y.

125 (Burke et al., 1978; Duncan and Hargraves, 1984). Furthermore, most models posit that the CLIP

126 was generated by the Galapagos plume over two major magmatic pulses of CLIP-related

127 magmatism at 92-88 Ma and 76-72 Ma (see Kerr et al., 2003, and references therein). Although

128 most of the CLIP is submerged beneath the Caribbean Sea, many on-land Late Cretaceous

129 igneous complexes in the Circum- Caribbean represent uplifted and/or accreted CLIP fragments.

130 These sub-aerially exposed CLIP complexes are located along the Pacific coast of South and

131 Central America, in western Ecuador and Colombia in the east and in Panama and the Nicoya

132 Peninsula in northwestern-most Costa Rica in the west (Fig. 1). CLIP exposures have also been

133 identified in the Leeward Antilles in Aruba and Curaçao to the north of Venezuela (Fig. 1).

134 The trench and continental shelf in front of Guatemala along the Pacific coast of Central

135 America were drilled during DSDP Leg 67 and Leg 84 (Geldmacher et al., 2008) to determine

136 the nature of the basement beneath the Central American forearc. Basement rocks include

137 ultramafic and mafic igneous rocks including basalts, dolerites, gabbros, serpentinized

138 peridotites and harzburgites (Geldmacher et al., 2008) and geophysical data from the lower

139 Nicaraguan margin wedge suggest a comparable dense basement spanning the front of its margin

140 (Walther et al., 2000). Seismic velocities intimate that the complete shelf between Costa Rica

141 and southern Mexico is underlain by igneous basement possibly similar to the subaerially

142 exposed Santa Elena and Nicoya igneous oceanic complexes (Ye et al., 1996; Walther et al.,

143 2000) in northwestern Costa Rica (Fig. 1). Plagiogranites of the Nicoya and Santa Elena

144 complexes are the focus of this contribution and we provide a synopsis of the nature and age of 145 these complexes below. 


\section{The Nicoya and Santa Elena complexes}

Four oceanic igneous complexes are located at or just to the south of the assumed

149 Chorotega-Chortis Block boundary in NW Costa Rica and from north to south, comprise the

150 Santa Elena, Nicoya, Tortugal and Herradura complexes, with Nicoya (Fig. 1) being the largest

151 and best studied of them (e.g., Dengo, 1962; Kuijpers, 1980; Hauff et al., 1997; Sinton et al.,

152 1997; Beccauluva et al., 1999; Hauff et al., 2000a; 2000b; Hoernle et al., 2004).

The Nicoya Complex largely consists of aphyric pillow and massive lava flows, which

154 are locally intruded by gabbros and plagiogranites (Hauff et al., 2000a) but also includes 155 dolerites, volcanic breccias and hyaloclastites (Denyer and Gazel, 2009). Magmatic ages of 156 Nicoya complex rocks range from 140-70 Ma (Hauff et al., 1997; Sinton et al., 1997; Hauff et 157 al., 2000a; Hoernle et al., 2004) though the majority of these ages are post 100 Ma as noted by 158 Whattam and Stern (2015), and dismembered radiolarite sequences of up to $100 \mathrm{~m}$ thickness 159 range from Callovian to Santonian (164-84 Ma) (e.g., Baumgartner, 1984; Schmidt-Effing, 160 1979). Rare occurrences of fossil-bearing intrapillow sediments, for example at Montezuma 161 (south Nicoya), indicate Cenomanian/Turonian (94 Ma) eruption ages (Azéma and Tournon, 162 1980; Tournon and Alvarado, 1997). ${ }^{40} \mathrm{Ar} /{ }^{39} \mathrm{Ar}$ step-heating analyses on seven lavas from Nicoya 163 yield a tight clustering of plateau ages which range from 92.5 $\pm 5.4 \mathrm{Ma}$ to $88.0 \pm 0.7 \mathrm{Ma}$ (Sinton 164 et al., 1997). Two intrusive rocks of the study of Sinton et al. (1997) returned plateau ages of $16583.8 \pm 1.1 \mathrm{Ma}$ and $83.2 \pm 1.3 \mathrm{Ma} . \mathrm{Via}{ }^{40} \mathrm{Ar} /{ }^{39} \mathrm{Ar}$ step-heating experiments, Hauff et al. (2000a) 166 dated a pillow lava from south Nicoya at $94.7 \pm 1.8 \mathrm{Ma}$ and plagioclase from a plagiogranite 167 from north Nicoya at $87.5 \pm 1.8 \mathrm{Ma}$. Collectively, and despite the range to much older ages 168 ( 140 Ma) obtained by Hoernle et al. (2004), the radiometric age data suggest formation of the 
169 bulk of the CLIP-derived igneous basement over a relatively short time interval between circa 95 170 and $83 \mathrm{Ma}$, which is in sharp contrast to the extensive biostratigraphic record of the radiolarites 171 (164-84 Ma). On the basis of a survey of literature data of biochronological and radiometric age 172 dates of circum-Caribbean oceanic magmatic complexes, Whattam and Stern (2015) suggested 173 the existence of two major pulses of oceanic plateau magmatism at 140-110 Ma, and a younger, 174 volumetrically dominant one after $100 \mathrm{Ma}$. Thus, the older biostratigraphic and radiometric ages 175 at Nicoya may be a record of an 'old' plateau whereas the post-100 Ma ages are a record of a 176 'younger' plateau.

177 At Santa Elena, a predominantly ultramafic nappe composed of serpentinized mantle 178 peridotites, and associated diabase instrusions, overthrusts a basalt-radiolarite assemblage that 179 also include layered gabbros, basaltic instrusions and plagiogranites (e.g. Azéma et al., 1985a; 180 Hauff et al., 2000a; Denyer et al., 2006; Gazel et al., 2006; Denyer and Gazel., 2009) (Fig. 1b). 181 Originally interpreted as part of the Nicoya Complex (Dengo, 1962; Kuipers, 1980), the Santa 182 Elena Complex is now considered to represent a distinct oceanic magmatic entity (Gazel et al., 183 2006; Madrigal et al., 2015). For example, though the ultramafic nappe and the mainly basaltic 184 Nicoya complex were considered as a genetically related ophiolitic suite (Azéma and Tournon, 185 1980; Beccaluva et al., 1999; Frisch et al., 1992), subsequent geochemical, geochronological and 186 isotopic studies established that basalts of Santa Elena are different from those of Nicoya (Hauff 187 et al., 2000a; Denyer et al., 2006; Denyer and Gazel, 2009; Madrigal et al., 2015).

188 As constrained by the age of the youngest underlying sediments, the Santa Elena 189 ultramafic nappe was emplaced after the Cenomanian (DeWever et al., 1985) but before the late 190 Campanian as constrained by the age of rudist reefs which lay atop the exhumed nappe 191 (Schmidt- Effing, 1980), which corresponds to an emplacement age of 93-75 Ma. This age range 
192 is supported by a radiometric $\mathrm{K} / \mathrm{Ar}$ age of $88 \pm 4.5 \mathrm{Ma}$ from a secondary amphibole sampled 193 from a recrystallized diabase dike (Bellon and Touron, 1978) and most probably dates 194 amphibolite metamorphism along shear zones related to the nappe emplacement.

195 On the basis of trace element and isotope chemistry, the Santa Elena nappe was 196 subdivided into four lithogical units by Hauff et al. (2000a). The first unit (also termed the 'Santa 197 Rosa Accretionary Complex', Baumgartner and Denyer, 2006; Denyer et al., 2006; Denyer and 198 Gazel, 2009) comprises oceanic island basalt (OIB)-like alkaline pillow lavas and dikes (Hauff et 199 al., 2000a) which are discordantly associated with circa 190-93 Ma radiolarian cherts. The 200 second and third units are comprised of basalts and layered gabbros, respectively for which $201{ }^{40} \mathrm{Ar} /{ }^{39} \mathrm{Ar}$ ages of $109 \pm 2 \mathrm{Ma}$ and $124 \pm 4$ Ma were obtained (Hauff et al., 2000a). According to 202 the subdivision of Hauff et al. (2000a), the ultramafic nappe comprises the fourth unit and in 203 terms of ultramafic nappe formation age, Madrigal et al. (2015) report ${ }^{40} \mathrm{Ar} /{ }^{39} \mathrm{Ar}$ ages of $\sim 131$ 204 Ma and 121 Ma for the timing of the Santa Elena peridotite cooling event as constrained by 205 pegmatitic gabbro intrusion and the formation and intrusion of later-formed diabase dikes, 206 respectively. Apart from the OIB-like alkaline basalts and dikes of Unit 1 of Hauff et al., (2000a), 207 the remaining Santa Elena lavas, gabbros and dikes which range from tholeiitic basalts to 208 basaltic andesites and trachyandesites have trace element and isotopic signatures consistent with 209 formation in a subduction zone environment (e.g., Hauff et al., 2000a; Gazel et al., 2006; 210 Hoernle and Hauff, 2007), possibly a back-arc basin (Madrigal et al., 2015).

\section{4. Methods}

\section{4.1. Petrography and mineral chemistry}


$215(n=2)$ were described under a petrographic microscope and petrographic features of these are

216 included below. Minerals of these samples were analyzed via a JEOL JXA-8600 SX electron

217 probe micro-analyzer (EPMA) at Korea University, Seoul, South Korea. Accelerating voltage,

218 beam current, and probe conditions were $15.0 \mathrm{kV}, 3.0 \mathrm{nA}$, and $3 \mu \mathrm{m}$, respectively.

\subsection{Whole rock chemistry}

221 We sampled fresh outcrops of plagiogranites for subsequent geochemical analysis (Table

222 1) along the coasts of the Santa Elena and Nicoya peninsulas in NW Costa Rica (Fig. 1). In the

223 Nicoya peninsula, the oceanic plutonic rocks are generally restricted to the northwest section of

224 the uplifted oceanic complex and are in metamorphic contact with radiolarian cherts or intruding

225 basaltic sequences (Fig. 1) (e.g., Denyer and Gazel, 2009). In the Santa Elena peninsula, the

226 collected samples are from a layered intrusion sequence that range from cumulate peridotites to

227 granites, and are limited to blocks within the metamorphic sole of the ophiolite and most likely

228 belonging to autochthonous lithologies below the peridotite nappe (Fig. 1) (Madrigal et al., 229 2015).

230 All samples were processed in the geochemistry laboratory at the Department of

231 Geosciences at Virginia Tech, following the procedures described in Mazza et al. (2014). Major 232 and trace element data were collected at the certified Activation Laboratories

233 (http://www.actlabs.com/) in Ancaster, Canada. The methods used included a lithium 234 metaborate/tetraborate fusion of the whole rock, which was then dissolved and analyzed by 235 Perkin Elmer Sciex ELAN 9000 ICP-MS. Three blanks and five controls (three before sample 236 group and two after) were analyzed per group of samples. Duplicates were fused and analyzed 
237 every 15 samples. The instrument was recalibrated every 40 samples. The accuracy for standards

238 BIR-1a, W-2 and J-1 run with samples is better than 5\% relative to the certified values for the

239 trace elements and better than $1 \%$ for major element data (with the exception of $\mathrm{Na}_{2} \mathrm{O}$ and $\mathrm{MnO}$,

240 better than $3 \%$ ). The blanks run with the samples were below the detection limit for all the

241 elements reported.

242 In addition to new geochemical data of Santa Elena and Nicoya plagiogranites (Table 1)

243 we also compile existing geochemical data of lavas and intrusives from Santa Elena (Beccaluva

244 et al., 1999; Hauff et al., 2000; Arias et al., 2002) and Nicoya (Ragazzi, 1996; Beccaluva et al.,

245 1999; Sinton et al., 1997; Hauff et al., 2000; Hoernle et al., 2004) for comparison with our data.

246 On our geochemical plots, all samples plotted are normalized to $100 \%$ in a volatile-free basis..

\section{3. $U$-Pb SHRIMP dating}

After sample pulverizing, zircons ranging from $63 \mu \mathrm{m}$ to $245 \mu \mathrm{m}$ were separated using 250 magnetic separation and heavy liquids. Separated zircons together with standard grains were 251 mounted in epoxy resin, polished to expose the middle of grain. The measured ${ }^{206} \mathrm{~Pb} /{ }^{238} \mathrm{U}$ ratio 252 was calibrated using the FC1 zircons (1099.0 Ma) standards, which were collected from the 253 gabbroic anorthosite of the Duluth Complex in Minnesota (Paces and Miller, 1993). Sri Lankan 254 gem zircon SL13 (U=238 ppm) was also used for calibration of $\mathrm{U}$ and Th concentrations. 255 Cathodoluminescence (CL) and backscattered electron (BSE) images were obtained using the 256 scanning electron microscopes of JEOL 6610LV at Korea Basic Science Institute (KBSI). The

257 phase identification of zircon and its inclusion were performed by INCA $x$-act energy dispersive 258 spectometer (EDS). Zircon U-Pb dating was carried out using the SHRIMP-IIe/MC at KBSI. The 259 analytical procedures for SHRIMP dating were mostly based on Williams (1998). A 20-25 $\mu \mathrm{m}$ 
260 spot size was used for all analyses under a negative ion oxygen beam $\left(\mathrm{O}_{2}^{-}\right)$in 3-4 nA of beam 261 current. The data were collected in sets of five scans throughout the mass measurements for each

262 isotope. For common $\mathrm{Pb}$ the ${ }^{206} \mathrm{~Pb} /{ }^{238} \mathrm{U}$ ages were corrected on the basis of the measured $263{ }^{207} \mathrm{~Pb} /{ }^{206} \mathrm{~Pb}$ ratio (Williams, 1998). FC-1 standard grains were repeatedly analyzed after every 264 three unknown analyses. Data reduction and processing were carried out using the Squid 2.50 265 and Isoplot 3.71 program of Ludwig (2008, 2009). When the drift in $\mathrm{Pb} / \mathrm{U}$ ratios of repeated FC2661 standard were obvious, the drift correction of secular varition was chosen on SQUID 2.5

267 software. Mean age of each specimen was calculated using ${ }^{207} \mathrm{~Pb}$-corrected ${ }^{206} \mathrm{~Pb}^{*}{ }^{238} \mathrm{U}$ ages after 268 excluding outliers under statistical $t$-test. Concordia diagrams were plotted using ${ }^{208} \mathrm{~Pb}$-corrected 269 ratios of ${ }^{206} \mathrm{~Pb} /{ }^{238} \mathrm{U}$ and ${ }^{206} \mathrm{~Pb} /{ }^{207} \mathrm{~Pb}$. All uncertainties in Tables 1 and 2 and Fig. 2 are given in $2701 \sigma$.

272 5. Results

273 5.1. Petrography and mineral chemistry

274 5.1.1. Nicoya diorites and plagiogranites

275 The SHRIMP-dated Nicoya diorite (3-23-11-10) and plagiogranites (1-23-11-10, 2-23-

276 11-10, 4-23-11-10 and CN-6-14-7-1) primarily comprise plagioclase and quartz with subordinate 277 but conspicuous large calcic amphibole (ferro-actinolite, typically <5\%) laths. Apatite, ilmenite, 278 magnetite and rare $(<1 \%)$ potassium feldspar occur as accessory phases. In the plagiogranites, 279 plagioclase and quartz constitute about $50-60 \%$ and $40-50 \%$ of the mode, respectively, whereas 280 in the diorite, plagioclase and quartz compose approximately $80-85 \%$ and $15-20 \%$ of the mode, 281 respectively. Both intrusive types are moderately altered and plagioclases are usually completely 282 saussuritized or sericitized and typically exhibit Carlsbad twins but no polysynthetic twins or 
283 obvious zonation. Plagioclase is generally more Na-rich in the diorite than in the plagiogranites

284 but both types comprise compositions that range to $\mathrm{Ab}_{100}$. Compositions of plagioclase cores and

285 rims of each intrusive type overlap and range from albite to andesine (diorite and plagiogranite

286 plagioclase cores exhibit $\left.\mathrm{Ab}_{100-55}\right)$. Micrographic granophyric intergrowths of albite and quartz

287 are common in both the diorite and the plagiogranites, similar to plagiogranites in general.

288 Actinolite occurs as discrete $0.2-5 \mathrm{~mm}$ pleochroic, green laths, the color owing to its Fe-rich

289 nature (33 wt. \% FeO), which are commonly altered to chlorite and present as inclusions that

290 occur with apatite needles within magnetite. Orthoclase occurs as micro $(\sim 5 \mu \mathrm{m})$ angular

291 inclusions within albite cores.

292

\section{5.1.2. Santa Elena plagiogranites}

294 The Santa Elena plagiogranite (SE-0401611-9) is petrographically and compositionally

295 distinct from the Nicoya diorites and plagiogranites. SE-0401611-9 is fresher and finer-grained

296 than the Nicoya felsic intrusives, contains relatively more quartz (up to $\sim 60 \%$ ) but lesser

297 plagioclase $(\sim 40-50 \%)$ than the latter and comprises a small volume of clinopyroxene $(<5 \%)$

298 instead of amphibole; potassium feldspar is absent. Some plagioclases are sericitized but not to

299 the degree of those in the felsic intrusives from Nicoya and many plagioclases exhibit

300 polysynthetic twins. Santa Elena plagiogranite plagioclase is also markedly more Ca-rich than

301 those of the Nicoya intrusives with cores and rims primarily of andesine $\left(\mathrm{An}_{18-52}\right)$; one

302 plagioclase core is oligoclase. Clinopyroxene is diopside $\left(\mathrm{Wo}_{48-50} \mathrm{En}_{25-34} \mathrm{Fs}_{16-28}\right.$, one core is

303 hedenbergite) and is present as $1 \mathrm{~mm}$ subhedral and anhedral light green, stubby prisms that are

304 usually altered to epidote and chlorite. Granophyric intergrowths of plagioclase and quartz which

305 are well-developed in the Nicoya intrusives are absent in the Santa Elena plagiogranite. 


\subsection{U-Pb SHRIMP dating}

Concordia plots are shown in Fig. 2 and individual spot analyses are given in Tables 2

309 and 3. CL images of selected zircon grains are shown in Fig. 3.

311 5.2.1. Zircon ages

Zircons from a total of six felsic samples, five from Nicoya and one from Santa Elena,

313 were dated via U-Pb SHRIMP methods. The five Nicoya samples include one diorite (4-23-11-

314 10) and four plagiogranite samples (1-23-11-10, 2-23-11-10, 3-23-11-10, CN-6-14-7-1) whereas

315 the lone Santa Elena sample (SE-040611-9) is a plagiogranite (these sample numbers and ages

316 obtained on these samples are shown in Fig. 1). The Nicoya samples yield ${ }^{206} \mathrm{~Pb} /{ }^{238} \mathrm{U}$ ages which

317 range from $\sim 87-93$ Ma while the Santa Elena plagiogranite cedes a ${ }^{206} \mathrm{~Pb} /{ }^{238} \mathrm{U}$ age of $125.3 \pm 2.0$

$318 \mathrm{Ma}$ (Fig. 2). Specifically, zircons from Nicoya diorite sample 4-23-11-10 yields a ${ }^{206} \mathrm{~Pb} /{ }^{238} \mathrm{U}$ age

319 of 88.9 22.1 Ma whereas plagiogranite samples 1-23-11-10, 2-23-110, 3-23-11-10 and CN-6-14-

$3207-1$ yield ${ }^{206} \mathrm{~Pb} /{ }^{238} \mathrm{U}$ ages of $88.5 \pm 2.0 \mathrm{Ma}, 88.6 \pm 1.7 \mathrm{Ma}, 89.1 \pm 1.1 \mathrm{Ma}$ and $90.9 \pm 2.0 \mathrm{Ma}$.

\subsubsection{Zircon morphology and zonation}

323 Nicoya plagiogranite zircons (Figs. 3a-f) range from $\sim 20-200 \mu \mathrm{m}$, are mainly subhedral 324 or anhedral and angular and typically exhibit complex zonation patterns (Figs. 3a, b). 325 Subordinate circa $\sim 70-160 \mu \mathrm{m}$ grains comprise elongated, subhedral to euhedral tabular prisms 326 which either lack zonation or exhibit thin, closely spaced, concentric zonation (Figs. 3c, d). A 327 small subset of $140-180 \mu \mathrm{m}$ grains are subhedral to anhedral and amorphous, and exhibit the 328 most complex zonation patterns (Figs. 3e, f). Santa Elena plagiogranite zircons are subhedral and 
329 commonly euhedral and typically smaller than most Nicoya plagiogranite zircons $(\sim 70-140 \mu \mathrm{m})$.

330 In contrast to Nicoya plagiogranite zircons, some of the Santa Elena plagiogranite zircons exhibit

331 simple zonation with broad, diffuse sector zones whereas others exhibit narrow, closely spaced

332 concentric zonation patterns similar to some Nicoya zircons (Figs. 3g, h).

\section{5.2.3. $U$ and Th concentrations and Th/U ratios}

335 Metamorphic zircons typically have low $\mathrm{Th} / \mathrm{U}$ ratios $<0.1$ which in many cases

336 discriminate these from magmatic zircons which usually exhibit much higher ratios (e.g., 337 Rubatto, 2002). All analyzed Santa Elena and Nicoya plagiogranite zircons have high $\mathrm{Th} / \mathrm{U}$ 338 ratios $>0.2$ (Santa Elena, 0.2-0.6 and Nicoya, 0.4-2.3, Fig. 4, Tables 2, 3) which demonstrates the 339 magmatic origin of both plagiogranite units. In addition to ranging to much higher $\mathrm{Th} / \mathrm{U}$ than 340 Santa Elena plagiogranite zircons, the Nicoya complex plagiogranite zircons also range to much 341 higher $U$ and Th concentrations than zircons of the Santa Elena plagiogranite. Nicoya 342 plagiogranite zircons exhibit a higher range in $\mathrm{U}$ and $\mathrm{Th}$ (79-1054 ppm and 35-1409 ppm) 343 relative to the Santa Elena plagiogranite which yields 57-357 ppm U and 13-202 ppm Th (Tables $3442,3)$.

\subsection{Plagiogranite whole rock major element chemistry}

Our suites of Nicoya $(n=8)$ and Santa Elena $(n=2)$ plagiogranites span 63-72 and 75-76

348 wt. \% $\mathrm{SiO}_{2}$, respectively. Chemical analyzes of Nicoya and Santa Elena intrusives are provided 349 in Table 1. Below we summarize the general major and trace element chemistry characteristics 350 of each plagiogranite suite. 


\subsubsection{Chemical classifications}

The Nicoya and Santa Elena plagiogranites ( $n=8,2$, respectively) have $\mathrm{SiO}_{2}$ contents

354 that range from $62.99-71.68$ wt. $\%$ and $75.30-75.53$ wt. \% corresponding to dacite and rhyolite 355 compositions on the $\mathrm{SiO}_{2}$ vs. total alkalis classification scheme of Le Bas et al. (1986) and $\mathrm{Al}_{2} \mathrm{O}_{3}$ concentrations of $11.68-13.37$ wt. $\%$ and 13.16-14.43 wt. \%. Both plagiogranite suites have very

357 low potassium (0.25-0.45 wt. $\% \mathrm{~K}_{2} \mathrm{O}$, Nicoya and 0.06-0.14 wt. \% $\mathrm{K}_{2} \mathrm{O}$, Santa Elena) typical of 358 all oceanic plagiogranites (e.g., Coleman and Donato, 1979) and each suite is enriched in $\mathrm{Na}_{2} \mathrm{O}$ 359 (4.67-5.92 wt. \%, Nicoya and 3.31-3.39 wt. \%, Santa Elena). The simple relation of Nicoya and 360 Santa Elena plagiogranites relative to mafic lavas and intrusives in $\mathrm{SiO}_{2}$ vs. $\mathrm{K}_{2} \mathrm{O}$ space (not 361 shown) suggests derivation of the former via fractional crystallization from the latter, which is 362 supported by the morphology of plagiogranite REE plots (see section below).

On the basis of petrography and the relative concentrations of plagioclase and quartz in

364 QAPF space, the Nicoya and Santa Elena plagiogranites are tonalities whilst the Nicoya diorite is 365 a quartz diorite-tonalite. However, on the basis of their molecular normative An-Ab-Or 366 compositions, all of our Nicoya and Santa Elena plagiogranites plot as trondhjemite and tonalite, 367 respectively, while one Nicoya plagiogranite from the literature also plots as tonalite (Fig. 5). 368 Plagiogranites of both Nicoya and Santa Elena are metaluminous according to the molecular $369 \mathrm{Al} /(\mathrm{Ca}+\mathrm{Na}+\mathrm{K})$ vs. $\mathrm{Al} /(\mathrm{Na}+\mathrm{K})$ and $\mathrm{SiO}_{2}$ vs. alumina saturation index (ASI, molecular $\mathrm{Al} / \mathrm{Ca}-$ 370 1.67P+Na+K) (Fig. 6) (Shand, 1947; Zen, 1988) discrimination plots of Maniar and Piccoli 371 (1989) and Frost and Frost (2008), respectively. Based on the $\mathrm{Ga}\left(10^{4}\right) / \mathrm{Al}$ vs. Zr plot of Whalen 372 et al. (1987), all Santa Elena plagiogranites are I- and S-type granites (Chappell and White, 1974) 373 whilst all but one Nicoya plagiogranite (with 57-63 wt. \% $\mathrm{SiO}_{2}$ which plots as an I- or S-type 374 granite) are A-type granites (Fig. 7). Nevertheless,, as is shown below, it is apparent that both the 
375 Nicoya and Santa Elena plagiogranite suites were derived via fractional crystallization and hence

376 are most accurately termed as M-type (mantle derived) granites (Chappell and White, 1974).

378 5.3.2. REE patterns

379 Oceanic plagiogranites have been show to form principally in two very different ways

380 (Summary in 1), either by fractional crystallization from a hydrous gabbroic source or less

381 commonly, via anatexis of mafic rocks. The particular formation mechanism can usually be

382 discriminated on the basis of REE patterns (e.g., Pedersen and Malpas, 1984). Whereas

383 plagiogranites formed by crustal melting will exhibit highly LREE fractionated patterns

384 dissimilar to associated mafic lavas and intrusives (e.g., Pedersen and Malpas, 1984),

385 plagiogranites formed via fractional crystallization will instead exhibit REE patterns with

386 morphologies that mimic associated mafic rocks (e.g., Bonev and Stampli, 2009). Via

387 comparison of plagiogranite REE signatures and those of associated mafics, an origin via 388 fractionation appears accurate for both the Nicoya and the Santa Elena plagiogranites (Fig. 8).

389 Moreover, via comparison of Nicoya and Santa Elena plagiogranites with global plagiogranites

390 constrained as forming via fractionation or anatexis (Fig. 9), the data appears to suggest

391 formation of the former via fractional crystallization. Below we provide fractional crystallization

392 and REE models to place constraints on the petrogenesis of Nicoya plagiogranites.

393

394 5.3.3. Fractional crystallization models and implications for origin of felsic magmas in oceanic 395 settings

396 In order to provide additional evidence for the origin of the plagiogranites found in the

397 Nicoya Peninsula within the CLIP oceanic suites, we produced fractional crystallization models 
using rhyolite-MELTS (Gauda et al., 2012). For these calculations, liquid lines of descent (LLD)

399 are plotted in Fig. 10, where every discontinuity in the line indicates a new crystallizing mineral

400 phase. We input a primary magma composition derived from CLIP primitive sample BH11

401 (Hauff et al., 2000a) by Herzberg and Gazel (2009). The calculations were made using the QFM

402 buffer appropriate for tholeiitic series (e.g., Zimmer et al., 2010). To evaluate the effect of

403 pressure we used two models at 0.5 and $5 \mathrm{kbars}$, and to assess the effect of water we incremented

404 water contents from anhydrous conditions to $1 \mathrm{wt} \%$, keeping the pressure constant during each

405 run. All the calculations were done at decreasing temperature intervals of $10{ }^{\circ} \mathrm{C}$, starting at the

406 liquidus temperature and ending at $600{ }^{\circ} \mathrm{C}$.

407 The major element variations are controlled by crystallization of different mineral phases

408 as temperature decreases and for oceanic suites is particularly important when the cotectic of 409 plagioclase and pyroxene starts. When this cotectic is reached, it is reflected by the negative 410 correlation between $\mathrm{SiO}_{2}$ and $\mathrm{Al}_{2} \mathrm{O}_{3}$ vs. $\mathrm{MgO}$ (Figs. 10a, b). The relative abundance of $\mathrm{Al}_{2} \mathrm{O}_{3}$ 411 will also increase as crystallization pressure increases, as the liquids in equilibrium with olivine+ 412 clinopyroxene will increase their $\mathrm{Al}_{2} \mathrm{O}_{3}$ content and this can lead to a higher modal plagioclase 413 content (Herzberg, 2004). If plagioclase crystallized before clinopyroxene, then $\mathrm{FeO}_{\mathrm{t}}$ and $\mathrm{TiO}_{2}$ 414 (not shown) will increase as these elements are not compatible in plagioclase (Zimmer et al., 415 2010). Finally, the $\mathrm{CaO}$ vs. $\mathrm{MgO}$ systematics can also be used to evaluate whether or not a melt 416 has crystallized clinopyroxene because $\mathrm{CaO}$ contents increase during the L+olivine and 417 L+olivine+plagioclase steps of crystallization and decrease as soon as the liquid starts to 418 crystallize olvine+plagioclase+clinopyroxene. The sensitivity of $\mathrm{CaO}$ to pressure effects was 419 evaluated by Langmuir et al. (1992), Herzberg (2004) and Madrigal et al. (2015). The felsic 420 Nicoya samples are too fractionated to constrain their pressures of fractionation, but the rest of 
421 the data are consistent with a range from shallow (0.5 bars) to relatively deep (5 kbars) 422 fractionation sequences.

423 We explored different water contents as the effect of small amounts of $\mathrm{H}_{2} \mathrm{O}$ which result

424 in a displacement of the cotectic points due to the suppression of plagioclase crystallization 425 relative to olivine and clinopyroxene is significant (e.g., Danyushevsky, 2001). The range of 426 water from anhydrous to $1 \mathrm{wt} \%$ is necessary to explain our data falling into range of MORB 427 (Asimow and Langmuir, 2003; Danyushevsky, 2001; Hirth and Kohlstedt, 1996) and plume428 derived magmas from Hawaii (Dixon and Clague, 2001). Nevertheless, felsic (>65 wt. \% $\mathrm{SiO}_{2}$ ) 429 MELTS model results with water contents of $1 \mathrm{wt} \%$ included primary hydrous phases (e.g., 430 muscovite) not found in the Nicoya samples. Additionally, when modeled at pressures $>5$ kbars 431 and 1\% water, garnet resulted as a stable phase, not consistent with the composition of these 432 samples. Therefore, we suggest that at least $0.5 \%$ wt water was necessary to produce the felsic 433 magmas via fractional crystallization but not more than $1 \mathrm{wt} \%$.

As a proof of concept we also produced fractional crystallization models using the REE 435 contents of the same primitive melt (BH11, Hauff et al., 2000a) via Rayleigh Fractionation. We 436 were able to successfully reproduce the composition of the plagiogranites in Nicoya by $85-90 \%$ 437 crystallization of a liquid that left fractionated $40 \%$ olivine/orthopyroxene, $20 \%$ clinopyroxene, $43820 \%$ plagioclase $+10 \%$ spinel (Fig. 11). We acknowledge that this is of course not a unique 439 solution but the importance of the internal consistency between the MELTS models and the 440 simple REE fractionation model point towards fractional crystallization as the probable process 441 that produced these leucocratic intrusions.

442 As a note of caution, MELTLS models satisfied the major element geochemistry and are 443 based on thermodynamic parameterization of experimental work (see Gauda et al., 2012). The 
444 REE modeling was done to confirm fractional crystallization as the possible process to produce

445 the rocks but it is a forward modeling constrained not by thermodynamics but by trace element 446 partition in theoretical phases. Neverthless, the overall mineral phases used to model the REE 447 partition are indeed suggested by MELTS, but the absolute modal abundances are model 448 dependent.

\subsubsection{Chemical constraints on tectonic environment of formation}

On the triangular $\mathrm{Hf}-\mathrm{Rb} / 10-\mathrm{Ta}(3)$ granite tectonic discrimination diagram of Harris et al.

453 field while one Nicoya plagiogranite sample from the literature plots within the within-plate 454 granite domain, in this case related to an oceanic plateu. In contrast, our two Santa Elena 455 plagiogranites plot within the volcanic arc granite field. Similar results are seen when the Nicoya 456 and Santa Elena plagiogranites are plotted on the granite discrimination plots of Pearce et al. 457 (1982). On all four plots ( $\mathrm{Y}+\mathrm{Nb}$ vs. Rb shown only in Fig. 10), the Santa Elena plagiogranites 458 fall within the volcanic arc granite field whereas the Nicoya plagiogranites almost always fall 459 within the ocean ridge granite domain (Fig. 12).

\section{6. Discussion and conclusions}

The chemistry of the Nicoya and Santa Elena plagiogranites suggest formation in a 463 MOR/oceanic plateau and an arc environment, respectively. Our findings for the Santa Elena 464 plagiogranites are consistent with the chemistry of associated Santa Elena mafic intrusives which 465 also point to a magmatic arc origin (e.g., Gazel et al., 2006; Escuder-Virute et al., 2015). In the case of Nicoya, many studies have demonstrated a plume-component in the genesis of the

467 Nicoya Complex and a linkage of Nicoya with the CLIP oceanic plateau (see Whattam and Stern, 
2015). For example, on various tectonomagmatic plots, the Nicoya plagiogranites consistently

469 plot with the MOR field but compositions do overlap into the within-plate granite field on some 470 plots.

471 Radiometric age determinations of rocks of the Nicoya Complex have been reported by 472 Sinton et al. (1997), Hauff et al. (2000a), and Hoernle et al. (2004) and ages of rocks comprising 473 the Santa Elena Complex have been documented by Hauff et al. (2000a) and Madrigal et al. 474 (2015). The study of Sinton et al. (1997) yielded ${ }^{40} \mathrm{Ar} /{ }^{39} \mathrm{Ar}$ plateau ages of 90-88 Ma with a 475 weighted mean of 88.5 Ma from basalts and diabases of Nicoya whereas Hauff et al. (2000a) 476 report ${ }^{40} \mathrm{Ar} /{ }^{39} \mathrm{Ar}$ plateau ages of $87.5 \pm 1.8 \mathrm{Ma}$ and $94.7 \pm 1.8 \mathrm{Ma}$ for a plagiogranite and tholeiitic

477 basalt, respectively, of Nicoya. These ages are in very close agreement with our U-Pb SHRIMP 478 dates for Nicoya plagiogranites which range from $88.5 \pm 2.0$ Ma to $90.9 \pm 2.0$ Ma. The study of 479 Hoernle et al. (2004) reported much older ${ }^{40} \mathrm{Ar} /{ }^{39} \mathrm{Ar}$ ages of $139 \pm 1$ Ma to $110.6 \pm 0.9$ Ma for 480 Nicoya basalts which Whattam and Stern (2015), on the basis of geochemical considerations, 481 considered to represent an earlier stage of volumetrically subordinate oceanic plateau 482 construction. Rocks of the Santa Elena ophiolite have been dated by radiometric age dating 483 methods by Hauff et al. (2000a) and Madrigal et al. (2015). The study of Hauff et al. (2000a) 484 yields ${ }^{40} \mathrm{Ar} /{ }^{39} \mathrm{Ar}$ ages of $109 \pm 2.0 \mathrm{Ma}$ and $124.0 \pm 4.0$ Ma for a pillow lava basalt and a layered 485 gabbro, respectively whereas Madrigal et al. (2015) provided ${ }^{40} \mathrm{Ar} /{ }^{39} \mathrm{Ar}$ ages that range from 486 131-121 Ma. Thus our U-Pb SHRIMP age of 125.3 $\pm 2.0 \mathrm{Ma}$ is in close agreement with the 487 basalt age of Hauff et al. (2000a) and the range of ages reported by Madrigal et al. (2015). Our 488 ages for both the Nicoya and Santa Elena plagiogranites fall within the midrange of ages from 489 the literature and represent the main magmatic phase of formation of the Nicoya and Santa Elena 490 complexes at $\sim 90 \mathrm{Ma}$ and $125 \mathrm{Ma}$, respectively. 
492 88.5 $\pm 2.0 \mathrm{Ma}, 88.6 \pm 1.7 \mathrm{Ma}, 88.9 \pm 2.1 \mathrm{Ma}, 89.1 \pm 1.1 \mathrm{Ma}$ and 90.9 $\pm 2.0 \mathrm{Ma}$ whereas a plagiogranite 493 of the Santa Elena Complex cedes a U-Pb SHRIMP age of 125.3 $\pm 2.0 \mathrm{Ma}$. Both sets of ages are

494 in close agreement with ages from the literature and represent the main magmatic stage of each 495 complex. Plagiogranites from both the Nicoya and Santa Elena complexes are consistent with a 496 fractional crystallization, as opposed to a partial melting, origin. In the case of the Nicoya 497 Complex, fractional crystallization models suggest that the plagiogranites formed via 85-90\% 498 fractional crystallization from its parental mafic source.

\section{Acknowledgments}

We thank Dr. Nikolay Bonev, an anonymous reviewer and Editor-in-Chief Nelson Eby supported in part by NSF awards EAR- 1221414 and EAR- 1201903 to E. Gazel.

\section{Figure Captions}

506 Fig. 1 Map of Nicoya peninsula and the Nicoya and Santa Elena complexes and (inset) the Circum-Caribbean 507 region. White stars with associated boxes demarcate sample numbers and their U-Pb ages from this study. The small 508 box in the inset represents the region shown of the Nicoya peninsula in the main map.

Fig. 2 Concordia plots of U-Pb SHRIMP dated (a-e) Nicoya and (f) Santa Elena plagiogranites. In each plot the

$511{ }^{208} \mathrm{~Pb}$-corrected/data-point error ellipses represent $68.3 \%$ confidence.

513 Fig. 3 Representative cathoduluminescence images of (a-f) Nicoya and (g, h) Santa Elena plagiogranite zircons.

515 Fig. $4 \mathrm{Th} / \mathrm{U}$ compositions of Nicoya and Santa Elena plagiogranite zircons. 
517 Fig. 5 Molecular Ab-An-Or plot of Nicoya and Santa Elena plagiogranites.

519 Fig. 6 Distribution of Nicoya and Santa Elena plagiogranites on the $\mathrm{SiO} 2$ vs. alumina saturation index (ASI) plot of 520 Frost and Frost (2008). Samples with 57-63 wt. \% $\mathrm{SiO}_{2}$ are marked by crosses; all other samples have $>63$ wt. \% $521 \mathrm{SiO}_{2}$. Data from the literature for Nicoya is from Ragazzi (1996), Sinton et al. (1997), Beccaluva et al. (1999) and 522 Hauff et al. (2000a) and data from the literature for Santa Elena is from Arias (2000).

524 Fig. 7 Distribution of Nicoya and Santa Elena plagiogranites on the $104 \mathrm{Ga} / \mathrm{Al}$ vs. Zr plot of Whalen et al. (1987).

525 Samples with 57-63 wt. \% $\mathrm{SiO} 2$ are marked by crosses; all other samples have $>63$ wt. \% $\mathrm{SiO} 2$.

527 Fig. 8 Chondrite normalized REE plots of (a) Nicoya and (b) Santa Elena plagiogranites. REE concentrations from 528 Sun and McDonough (1989). Abbreviations within boxes within individual plots: int, intrusive; lit, literature (data).

530 Fig. 9 Chondrite normalized REE plots of (a) Nicoya and (b) Santa Elena plagiogranites versus ophiolitic 531 plagiogranites formed via fractional crystallization (Semail, Troodos, Visnes) and anatexis (East Karmoy). Ophiolite 532 data sources: East Karmoy and Visnes, Pedersen and Malpas (1984); Semail, Pallister and Knight (1981); Troodos, 533 Thy et al. (1985). Abbreviations within boxes within individual plots: int, intrusive; lit, literature (data).

535 Fig. 10 Fractional crystallization models for the Nicoya plagiogranites.

537 Fig. 11 Fractional crystallization models using REE contents for the Nicoya plagiogranites.

539 Fig. 12 Compositions of Nicoya and Santa Elena plagiogranites on the $\mathrm{Y}+\mathrm{Nb}$ vs. Rb plot of Pearce et al. (1982).

540 Samples plotted have $>63$ wt. $\% \mathrm{SiO}_{2}$. Data from the literature for Nicoya is from Beccaluva et al. (1999) and Hauff 541 et al. (2000a) and data from the literature for Santa Elena is from Arias (2000). 
Table Captions

544 Table 1 ICP-MS whole rock major and trace element analyses of Nicoya and Santa Elena plagiogranites.

Table 2 U-Th SHRIMP analyses of zircons from Nicoya plagiogranites.

Table 3 U-Th SHRIMP analyses of zircons from Nicoya plagiogranites.

\section{References}

Arias, O., 2000.. Geologia y petroliia magmancana der bloque Herradura (Cretacico Superior-Eoceno), Costa Rica. Ph.D. thesis, Université de Lausanne, 186 pp.

Beccaluva, L., Chinchilla-Chaves, A.L., Coltorti, M., Giunta, G., Siena, F., Vaccaro, C., 1999. Petrological and structural significance of the Santa Elena-Nicoya Ophiolitic Complex in Costa Rica and geodynamic implications. European Journal of Mineralogy 11, 1091-1107.

Bonev, N., Stampfli, G., 2009. Gabbro, plagiogranite and associated dykes in the suprasubduction zone Evros Ophiolites, NE Greece. Geological Magazine 146, 1, 72-91.

Boven, A., Pasteels, P., Punzalan, L.E., Liu, J., Luo, X, Zhang, W., Guo, Z., and Hertogen, J., 2002. ${ }^{40} \mathrm{Ar}{ }^{39} \mathrm{Ar}$ geochronological constraints on the age and evolution of Permo-Triassic Emeishan volcanic province, Southwest China. Journal of Asian Earth Sciences 20, 157-175.

Chappell, B.W., White, A.J.R., 1974. Two contrasting granite types. Pacific Geology 8, 173-174.

Coleman, R.G., Donato, M.M., 1979. Oceanic plagiogranite revisited. In: Barker, F. (Ed.), Trondhjemites, dacites and related rocks. Elsevier Scientific Publishing Company. Amsterdam-Oxford-New York.

Coleman, R.G., Peterman, Z.E., 1975. Oceanic plagiogranite. Journal of Geophysical Research 80(8), 1099-1108.

Crawford, A.J., Beccaluva, L., Serri, G., 1981. Tectonomagmatic evolution of the West Philippine-Mariana region and the origin of boninites. Earth and Planetary Science Letters 54, 346-356.

Danyushevsky, L.V., 2001. The effect of small amounts of $\mathrm{H} 2 \mathrm{O}$ on crystallisation of mid-ocean ridge and backarc basin magmas. Journal of Volcanology and Geothermal Research 110, 265-280.

Denyer, P., Gazel, E., 2009. The Costa Rican Jurassic to Miocene oceanic complexes: Origins, tectonics and relations. Journal of South American Earth Sciences 28, 429-442. 
Diebold, J., Driscoll, P., 1999. New insights on the formation of the Caribbean basalt province revealed by multichannel seismic images of volcanic structures in the Venezuelan Basin: In: Caribbean Sedimentary Basins, Sedimentary Basins of the World, Mann, P. (ed.), Elsevier, pp. 561-589.

Dixon, J. E., Clague, D., 2001. Volatiles in basaltic glasses form Lohihi Semount, Hawaii: Evidence for a relative dry Plume Component. Journal of Petrology, 42(3), 627-654.

Dixon S., Rutherford, M.J., 1979. Plagiogranites as late-stage immiscible liquids in ophiolite and mid-oceanic ridge suites: An experimental study. Earth and Planetary Science Letters 45, 45-60.

Dixon-Spulber, S., Rutherford, M.J., 1983. The origin of rhyolite and plagiogranite in oceanic crust: An experimental study. Journal of Petrology 24, 1-25.

Elliot, T., Plank, T., Zindler, A., White, W., Bourdon, B., 1997. Element transport from slab to volcanic front at the Mariana arc. Journal of Geophysical Research 102, 14991-15019.

Escuder-Viruete, J., Baumgartner, P.O., Castillo-Carrión, M., 2015. Compositional diversity in peridotites of result of a multi-process history: The Pacific-derived Santa Elena ophiolite, northwest Costa Rica. Lithos 231, 16-34.

Falloon, T.J., Malahoff, A., Zonenshain, L.P., Bogdanov, Y., 1992. Petrology and geochemistry of back-arc basin basalts from the Lau Basin spreading ridges at $15^{\circ}, 18^{\circ}$ and $19^{\circ} \mathrm{S}$. Mineralogy and Petrology 47, 1 35.

Flagler, P.A., Spray, J.G., 1991. Generation of plagiograite by amphibolite anatexis in oceanic shear zones. Geology 19, 70-73.

Floyd, P.A., Yaliniz, M.K., Goncuoglu, M.C., 1998. Geochemistry and petrogenesis of intrusive and extrusive ophiolitic plagiogranites, Central Anatolian Crystalline Complex, Turkey. Lithos 42, 225-241.

France, L., Koepke, J., Ildefonse, B., Cichy, S.B., Deschamps, F., 2010. Hydrous partial melting in the sheeted dyke complex at fast spreading ridges: Experimental and natural observations. Contributions to Mineralogy and Petrology 160, 683-704.

Frost, B.R., Frost, C.D., 2008. A geochemical classification for feldspathic igneous rocks. Journal of Petrology 45, 1955-1969.

Gazel, E., Denyer, P., Baumgartner, P.O., 2006. Magmatic and geotectonic significance of Santa Elena peninsula. Geologica Acta 4(1-2), 193-202. 
Gilluly, J., 1933. Replacement origin of the albite granite near Sparta, Oregon. U.S. Geological Survey Professional Paper 1750, 65-81.

Gualda, G. A. R., M. S. Ghiorso, R. V. Lemons, and T. L. Carley (2012), Rhyolite-MELTS: a Modified Calibration of MELTS Optimized for Silica-rich, Fluid-bearing Magmatic Systems, Journal of Petrology 53(5), 875-890.

Harley, S. L., Kelley, N. M., Möller, A., 2007. Zircon behavior and the thermal histories of mountain chains. Elements 3, 25-30.

Harris, N.B.W., Pearce, J.A., Tindle, J.G., 1986. Geochemical characteristics of collision-zone magmatism. In: Coward, M.P., Reis, A.C. (Eds.), Collision tectonics. Special Publication of the Geological Society 19, pp. $67-81$.

Hauff, F., Hoernle, K., Tilton, G., Graham, D.W., Kerr, A.C., 2000a. Large scale recycling of oceanic lithosphere over short time scales: geochemical constraints from the Caribbean Large Igneous Province. Earth and Planetary Science Letters 174, 247-263.

Hauff, F., Hoernle, K., van der Bogard, P., 2000b. Age and geochemistry of basaltic complexes in western Costa Rica: contributions to the geotectonic evolution of Central America. Geochemistry, Geophysics, Geosystems 1 (Paper number 1999GC000020).

Herzberg, C., 2004. Partial Crystallization of Mid-Ocean Ridge Basalts in the Crust and Mantle, Journal of Petrology

616 Herzberg, C., Gazel, E., 2009. Petrological evidence for secular cooling in mantle plumes, Nature 458(7238), 619-622.

617 Hoernle, K., Hauff, F., van den Bogaard, P., 2004. 70 m.y. history (139-69 Ma) for the Caribbean large igneous $618 \quad$ province. Geology 32, 697-700.

619 Isozaki, Y., 1997. Contrasting two types of orogen in Permo-Triassic Japan: Accretionary versus collisional. The $620 \quad$ Island Arc 6, 2-24.

621 Jiang, Y.-H., Liao, S.-Y., Yang, W.-Z., Shenm W.-Z., 2008. An island arc origin of plagiogranites at Oytag, western Kunlun orogen, northwest China: SHRIMP zircon U-Pb chronology, elemental and Sr-Nd-Hf isotopic geochemistry and Paleozoic tectonic implications. Lithos 106, 323-335.

624 Koepke, J., Berndt, J., Feig, S.T., Holz, F., 2007. The formation of $\mathrm{SiO}_{2}$-rich melts within the deep oceanic crust by hydrous partial melting of gabbros. Contributions to Mineralogy and Petrology 153, 67-84 
Langmuir, C.H., Klein, E.M., Plank, T., 1992. Petrological systematics of mid-ocean ridge basalts: Constraints on melt generation beneath ocean ridges. Geophysical Monograph Series 71, 183-280.

Le Bas, M.J., Le Maitre, R.W., Streckeisen, A., Zanettin, B., 1986. A chemical classification of volcanic rocks based on total alkali-silica diagram. Journal of Petrology 27, 745-750.

Lippard, S.J., Shelton, A.W., Gass, I.G., 1986. The ophiolite of Northern Oman. In: Geological Society Memoir, 11. Blackwell, Oxford, pp 178.

Ludwig, K. R., 2008. User's manual for Isoploe 3.6: a Geochronological Toolkit for Microsoft Excel. Berkeley Geochronology Center Special Publication, Berkeley.

634 Ludwig, K. R., 2009. User's manual for SQUID 2. Berkeley Geochronology Center Special Publication, Berkeley.

Madrigal, P., Gazel, E., Denyer, P., Smith, I., Jicha, B., Flores, K.E., Coleman, D., Snow, J., 2015. A meltfocusing zone in the lithospheric mantle preserved in the Santa Elena ophiolite, Costa Rica. Lithos 230, 189-205.

Maniar, P.D., Piccoli, P.M., 1989. Tectonic discrimination of granitoids. Geological Society of America Bulletin $101,635-643$.

Maufrett, A., Leroy, S., 1997. Seismic stratigraphy and structure of the Caribbean igneous province, Tectonophysics 293, 61-104. Pallister, J.S., Knight, R.J., 1981. Rare-earth element geochemistry of the Samail ophiolite near Ibra, Oman. Journal of Geophysical Research 86, 2673-2697.

Paces, J. B., Miller, J. D., 1993. Precise U-Pb ages of Duluth Complex and related mafic intrusions, Northeastern Minnesota: Geochronological insights to physical, petrogenic, paleomagnetic, and tectonomagmatic processes associated with the $1.1 \mathrm{Ga}$ mid-continent rift system. Journal of Geophysical Research-Solid Earth 98, 13997-14013.

Pallister, J.S., Knight, R.J., 1981. Rare-earth element geochemistry of the Samail ophiolite near Ibra, Oman. Journal of Geophysical Research B86, 2673-2697.

Pearce, J.A., 2008. Geochemical fingerprinting of oceanic basalts with applications to ophiolite classification and the search for Archean oceanic crust. Lithos 100, 14-48.

Pearce, J.A., Harris, N.B.W., Tindle, A.G., 1984. Trace element discrimination diagrams for the tectonic interpretation of granitic rocks. Journal of Petrology 25, 956-983. 
654 Pearce, J.A., Stern, R.J., Bloomer, S.H., Fryer, P., 2005. Geochemical mapping of the Mariana arc-basin system: 655 Implications for the nature and distribution of subduction components. Geochemistry, Geophysics, 656 Geosystems 6(7), Q07006, doi:10.1029/2004GC000895.

657 Pedersen, R., Malpas, J., 1984. The origin of oceanic plagiogranites from the Karmoy ophiolite, western Norway. Contributions to Mineralogy and Petrology 88, 36-52.

659 Ragazzi, C., 1996. Petrologia e geologia del Complesso Ofiolitico di Nicoya-St. Elena (Costa Rica). PhD Thesis. 660 Università degli Studi di Ferrara, 115 pp.

661 Rubatto, D., 2002. Zircon trace element geochemistry: partitioning with garnet and the link between U-Pb ages 662 and metamorphism. Chemical Geology 184, 123-138.

663 Shand, S.J., 1947. The eruptive rocks, $3^{\text {rd }}$ Edition. New York, John Wiley, 444 pp.

664 Sigvaldson, G.E., 1974. The petrology of Hecla and origin of silicic rocks in Iceland. In: The eruption of Hecla 665 1947-48. V. 1, Sci Icelandica, 44pp.

666 Sinton, C.W., Duncan, R.A., Denyer, P., 1997. Nicoya Peninsula, Costa Rica: a single suite of Caribbean oceanic plateau magmas. Journal of Geophysical Research 102, 507-515. http://dx.doi.org/10.1029/97JB00681.

668 Sun, S.S., McDonough, W.F., 1989. Chemical and isotopic systematic of oceanic basalts: implications for mantle 669 composition and processes. In: Saunders, A.D., Norry, M.J. (Eds.), Magmatism in the Ocean Basins. Geological Society of London Special Publication 42, pp. 313-345.

671 Thy, P., Brooks, C.K., Walsh, J.N., 1985. Tectonic and petrogenetic implications of major and rare earth element 672 chemistry of Troodos glasses, Cyprus. Lithos 18, 165-178.

673 Whalen, J.B., Currie, K.L., Chappell, B.W., 1987. A-type granites: Geochemical characteristics, discrimination and petrogenesis. Contributions to Mineralogy and Petrology 95, 407-419.

675 Whattam, S.A., Stern, R.J. 2015. Late Cretaceous plume-induced subduction initiation along the southern margin 676 of the Caribbean and NW South America: The first documented example with implications for the onset of plate tectonics. Gondwana Research 27, 38-63.

678 Whattam, S.A., Stern, R.J., 2016. Arc magmatic evolution and the construction of continental crust at the Central 679 American Volcanic Arc system. International Geology Review http://dx.doi.org/10.1080/00206814.2015.1103668. 
Williams, I.S., 1998. U-Th-Pb geochronology by ion microprobe, In: McKibben, M.A., ShanksIII III, W.C., Ridley, W.L. (Eds.), Applications of Microanalytical Techniques to Understanding Mineralizing Processes. Society of Economic Geologists, Socorro, Reviews in Economic Geology 7, pp. 1-35.

684 Zen, E., 1988. Phase relations of peraluminous granitic rocks and their petrogenetic implications. Annual Review of Earth and Planetary Sciences 16, 21-52.

686 Zimmer, M. M., T. Plank, E. H. Hauri, G. M. Yogodzinski, P. Stelling, J. Larsen, B. Singer, B. Jicha, C. Mandeville, and C. J. Nye (2010), The Role of Water in Generating the Calc-alkaline Trend: New Volatile Data for Aleutian Magmas and a New Tholeiitic Index. Journal of Petrology 51(12), 2411-2444. 


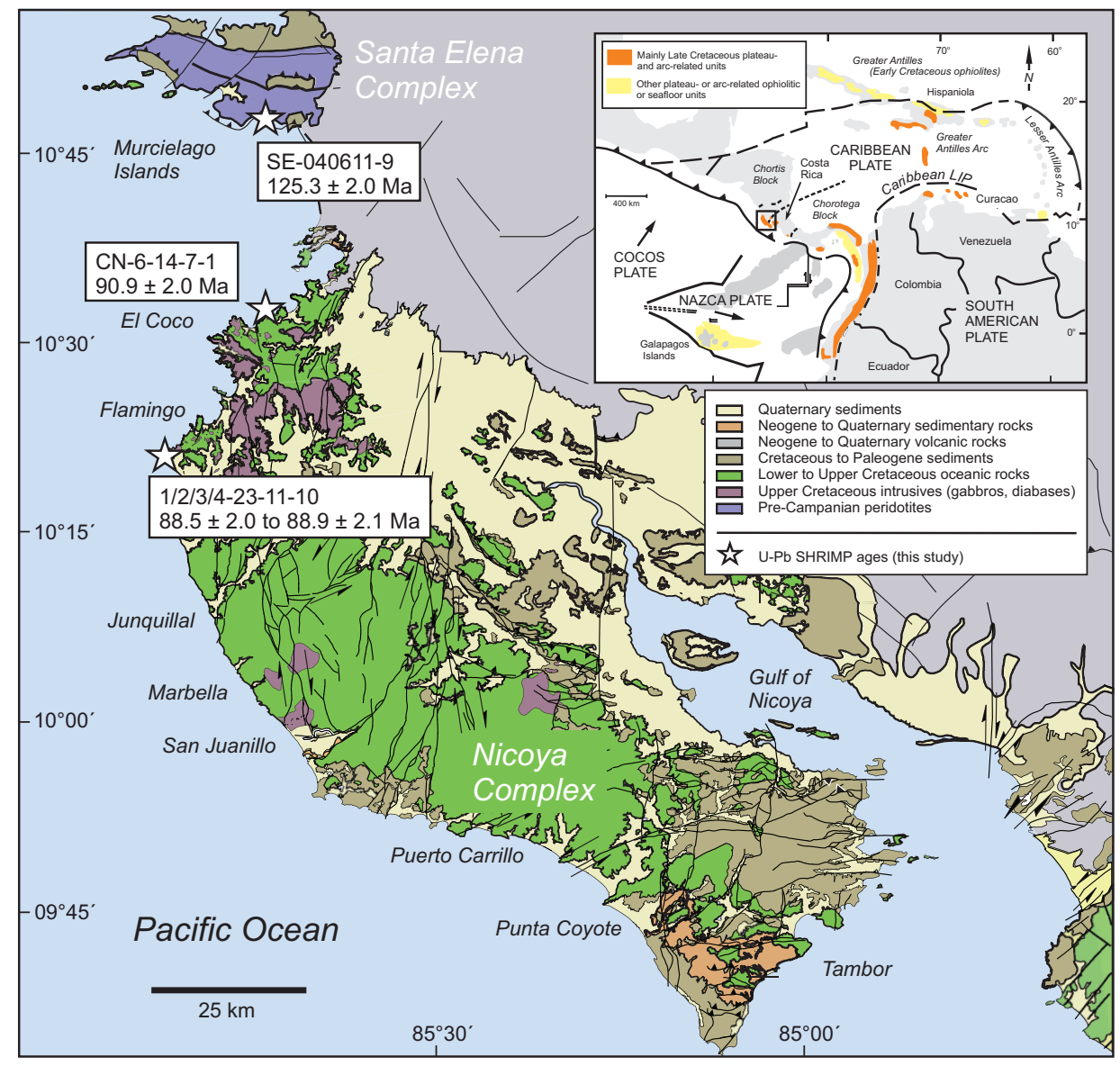

Figure 1 Whattam et al. (2016) 

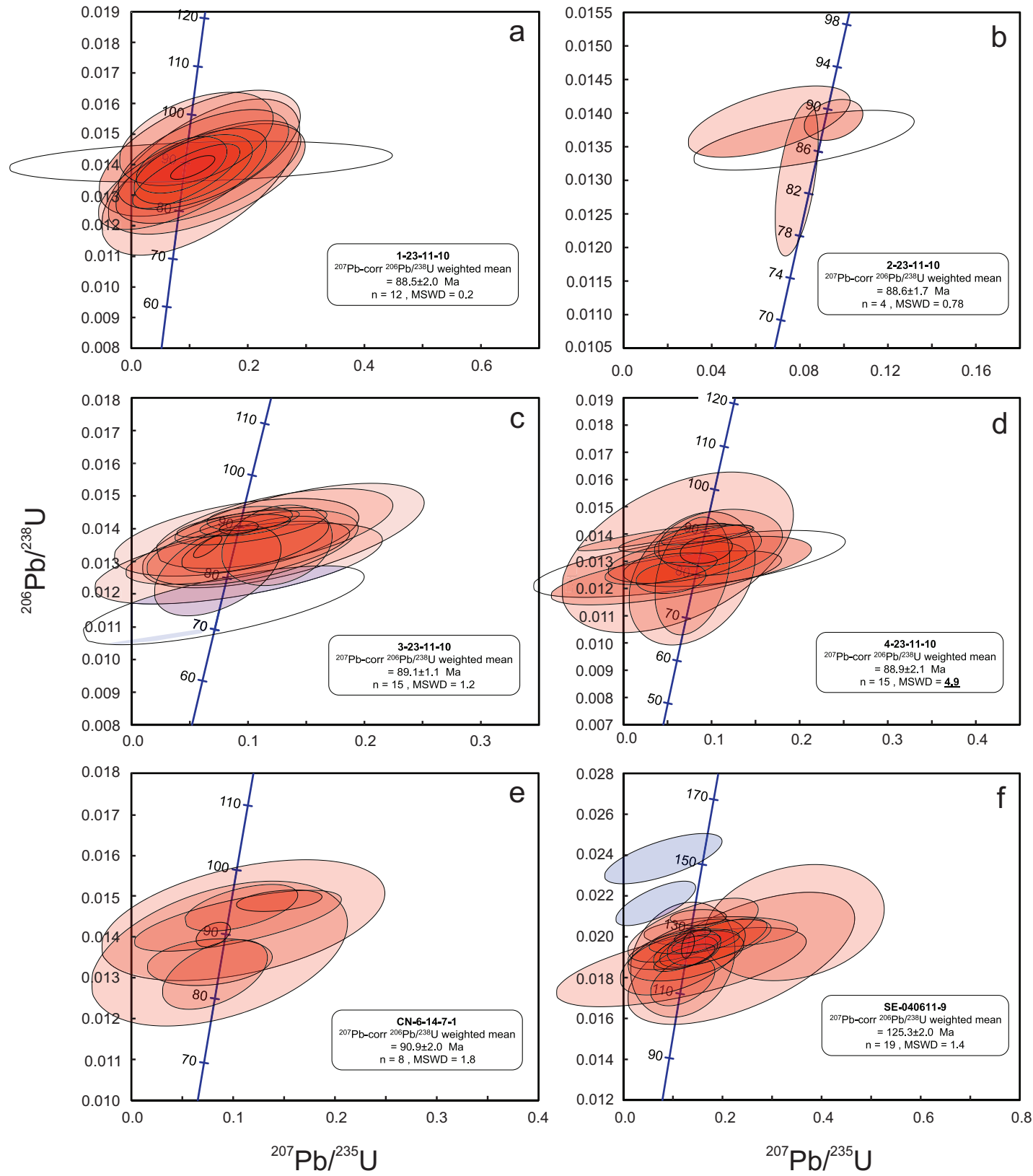

Figure 2 Whattam et al. (2016) 

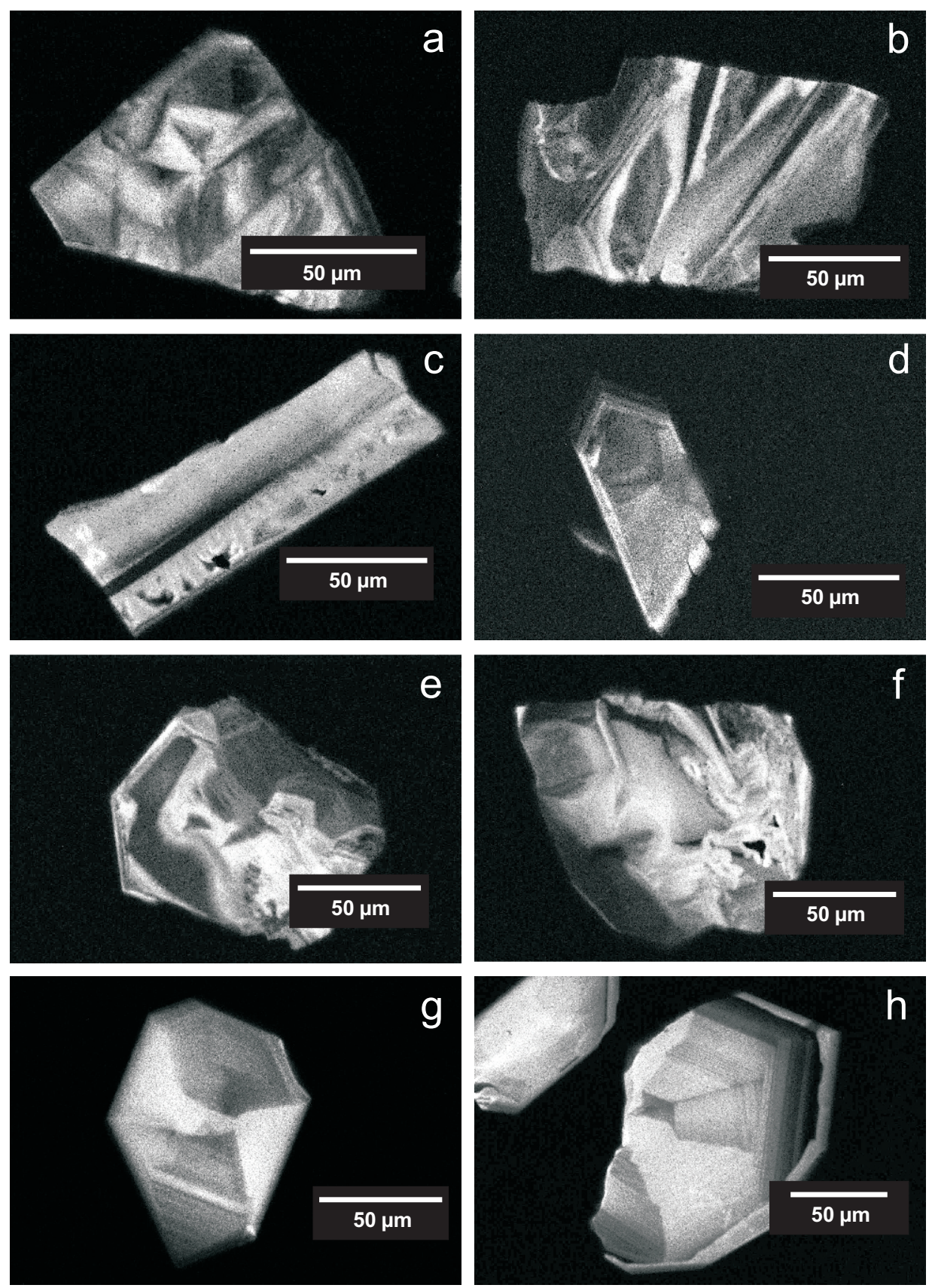

Figure 3 Whattam et al. (2016) 


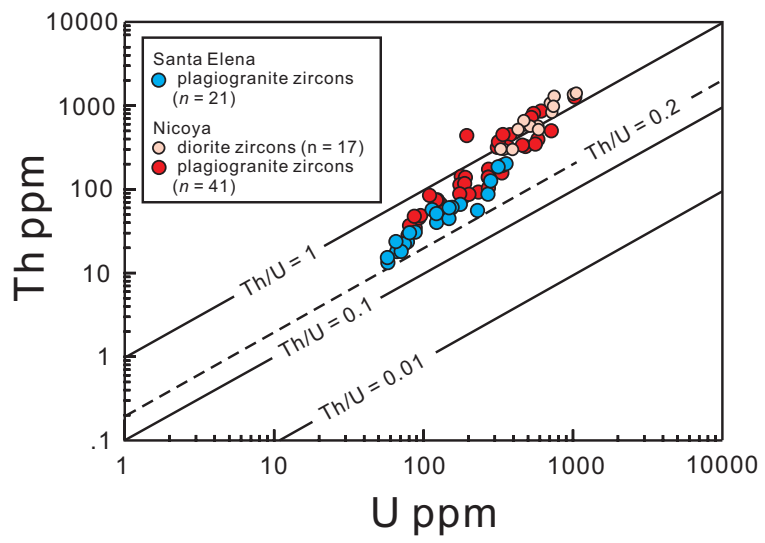

Figure 4 Whattam et al. 2016 


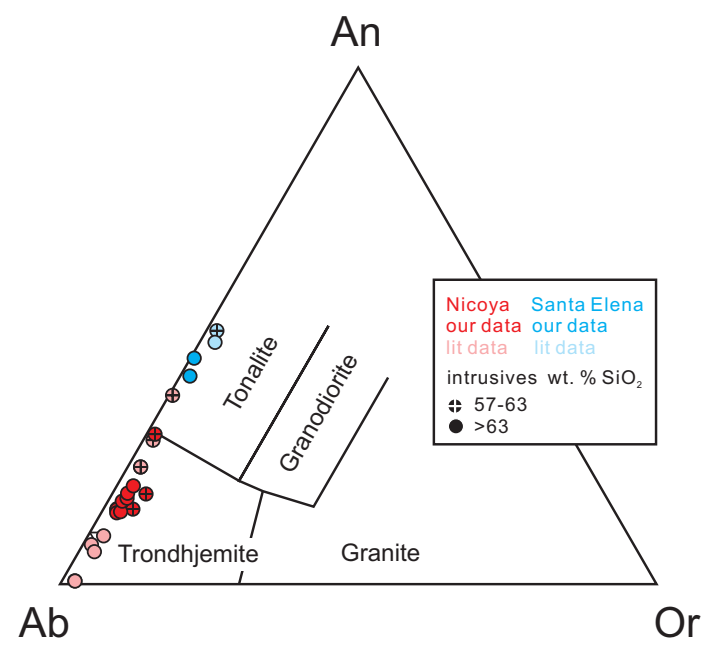

Figure 5 Whattam et al. (2016) 


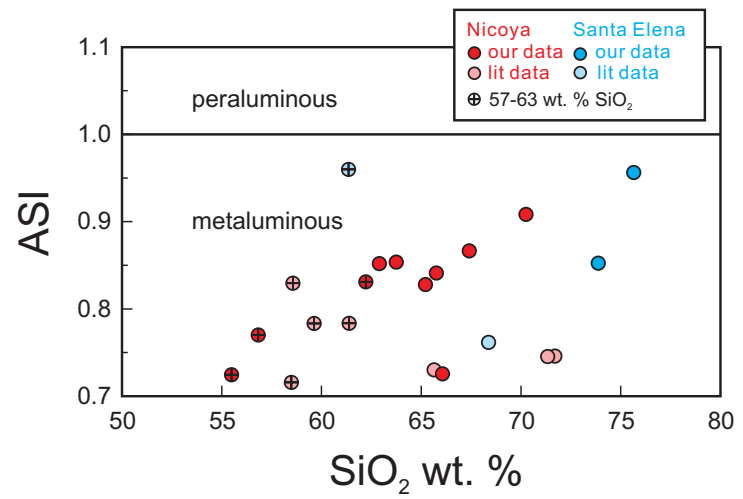

Figure 6 Whattam et al. (2016) 


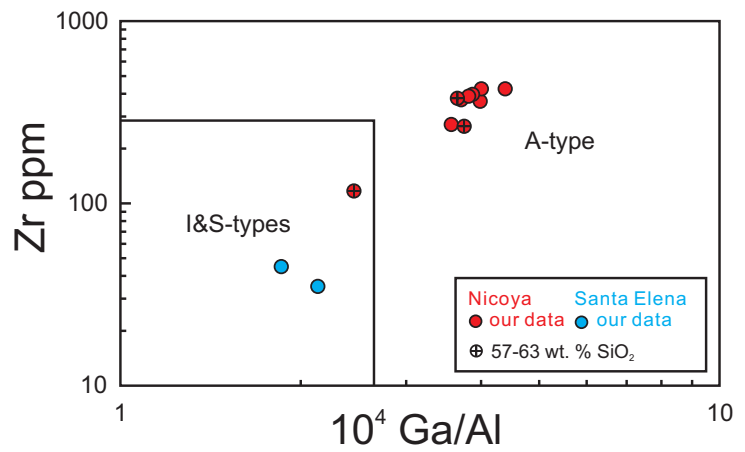

Figure 7 Whattam et al. (2016) 


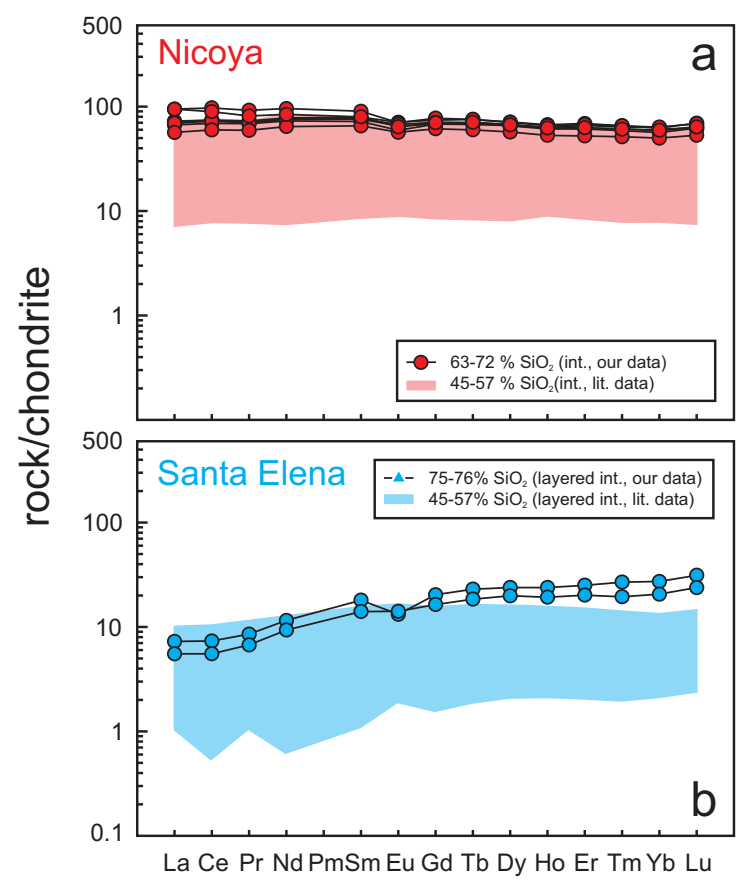

Figure 8 Whattam et al. 2016 


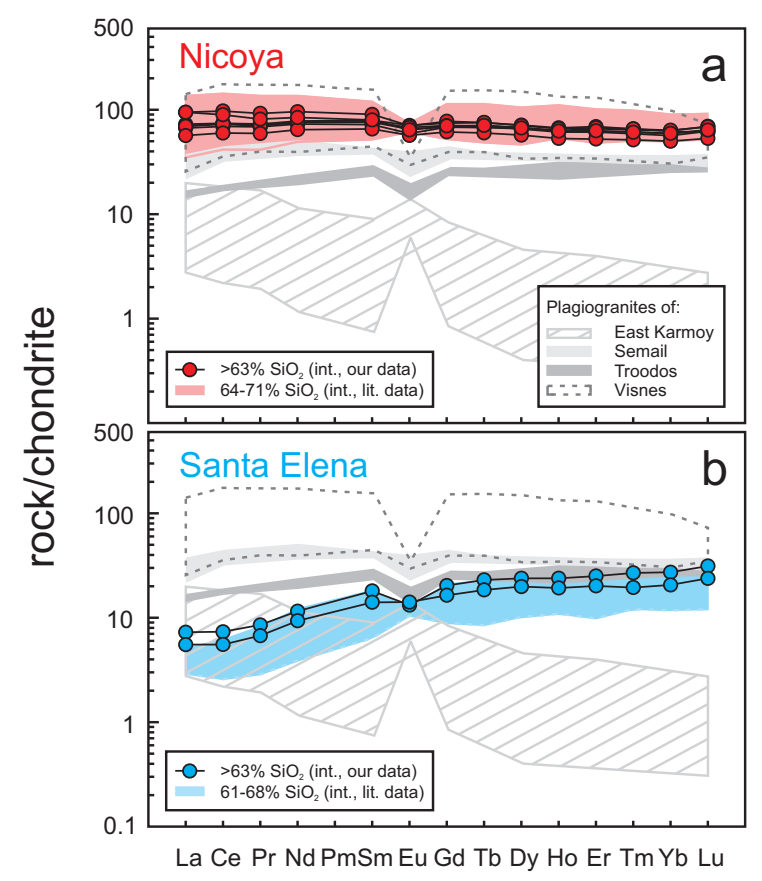

Figure 9 Whattam et al. 2016 

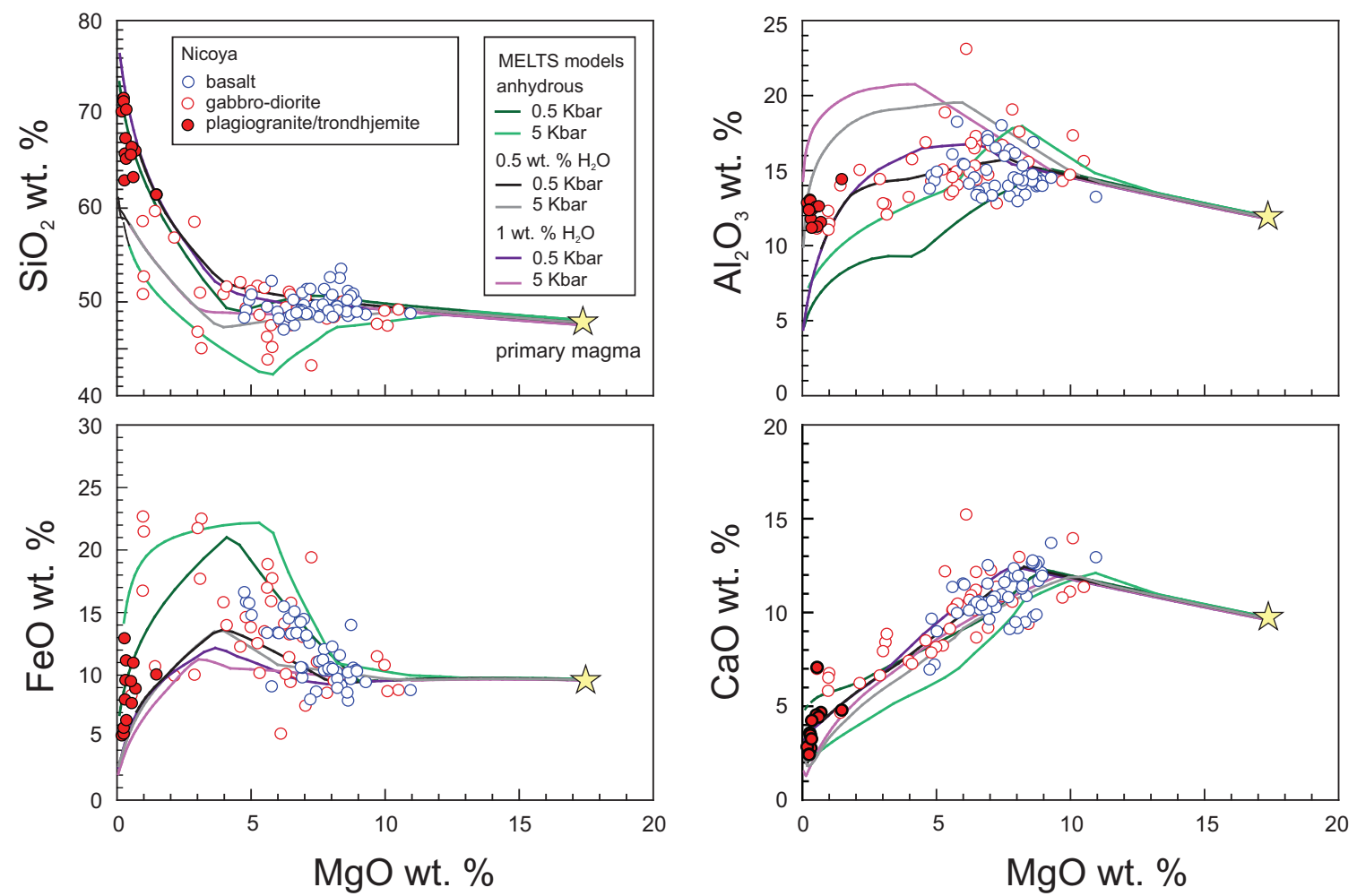

Figure 10 Whattam et al. (2016) 


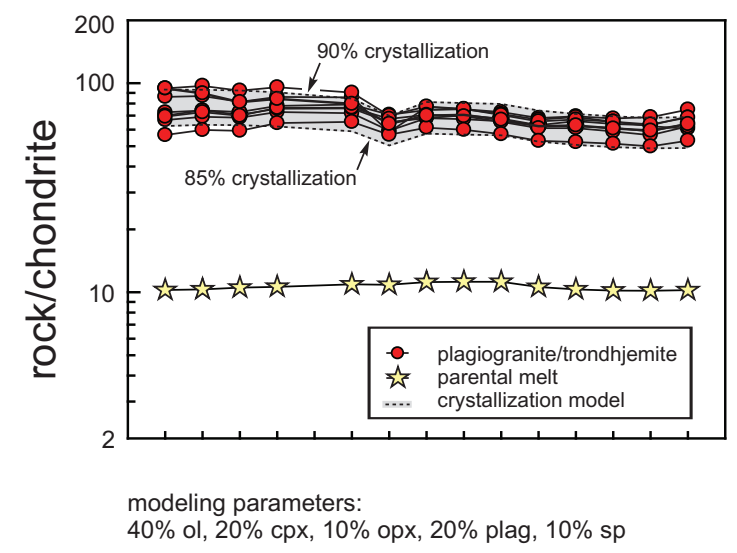

Figure 11 Whattam et al. (2016) 


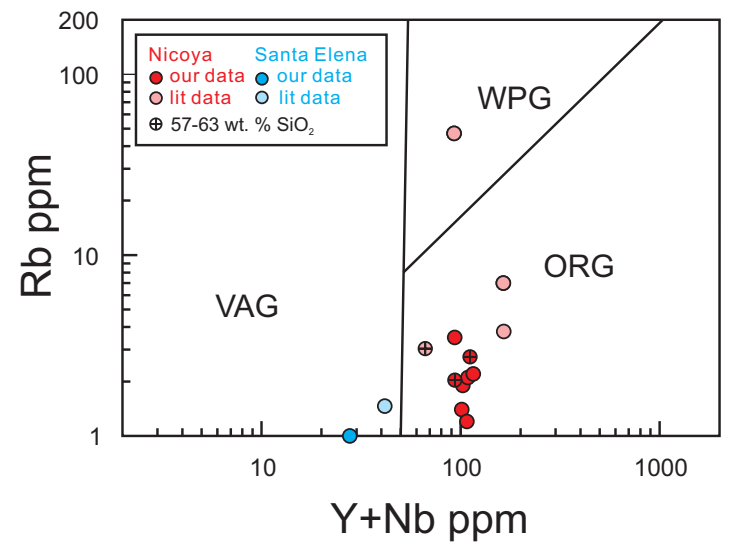

Figure 12 Whattam et al. 2016 
Table 1

ICP-MS whole rock major and trace element analyzes of Nicoya and Santa Elena plagiogranites

\begin{tabular}{|c|c|c|c|c|c|c|c|c|c|c|}
\hline \multirow{3}{*}{$\begin{array}{l}\text { Sample No. } \\
\text { Complex } \\
\text { Lithology }\end{array}$} & $4-23-11-10$ & $2-23-11-10$ & CN-6-14-7-1 & $1-23-11-10$ & OC-030512-1 & \multirow{3}{*}{$\begin{array}{l}\text { OC-030512-2 } \\
\text { Nicoya } \\
\text { plagiogranite }\end{array}$} & \multirow{3}{*}{$\begin{array}{l}\text { OC-030512-3 } \\
\text { Nicoya } \\
\text { plagiogranite }\end{array}$} & \multirow{3}{*}{$\begin{array}{c}\text { OC-030512-4 } \\
\text { Nicoya } \\
\text { plagiogranite }\end{array}$} & \multirow{3}{*}{$\begin{array}{c}\text { SE-040611-9 } \\
\text { Santa Elena } \\
\text { plagiogranite }\end{array}$} & \multirow{3}{*}{$\begin{array}{c}\text { SE-040611-A } \\
\text { Santa Elena } \\
\text { plagiogranite }\end{array}$} \\
\hline & Nicoya & Nicoya & Nicoya & Nicoya & Nicoya & & & & & \\
\hline & diorite & \multicolumn{2}{|c|}{ plagiogranite plagiogranite } & plagiogranite & plagiogranite & & & & & \\
\hline \multicolumn{11}{|c|}{ major oxides (wt. \%) } \\
\hline $\mathrm{SiO}_{2}$ & 62.23 & 67.41 & 63.75 & 70.25 & 62.90 & 65.76 & 65.21 & 66.07 & 75.65 & 73.88 \\
\hline $\mathrm{TiO}_{2}$ & 0.76 & 0.70 & 0.84 & 0.42 & 0.91 & 0.83 & 0.85 & 1.09 & 0.21 & 0.23 \\
\hline $\mathrm{Al}_{2} \mathrm{O}_{3}$ & 11.43 & 11.75 & 12.97 & 12.83 & 13.03 & 12.95 & 12.34 & 11.54 & 14.45 & 12.91 \\
\hline $\mathrm{FeO}$ & 11.71 & 9.56 & 9.67 & 5.14 & 12.91 & 8.01 & 11.14 & 8.89 & 0.74 & 2.00 \\
\hline $\mathrm{MnO}$ & 0.10 & 0.09 & 0.11 & 0.07 & 0.12 & 0.10 & 0.11 & 0.18 & 0.02 & 0.03 \\
\hline $\mathrm{MgO}$ & 0.45 & 0.33 & 0.33 & 0.19 & 0.29 & 0.31 & 0.35 & 0.70 & 0.38 & 0.29 \\
\hline $\mathrm{CaO}$ & 2.96 & 2.73 & 3.12 & 2.81 & 3.55 & 3.43 & 3.23 & 4.64 & 5.22 & 5.34 \\
\hline $\mathrm{Na}_{2} \mathrm{O}$ & 4.97 & 5.19 & 5.74 & 5.38 & 5.38 & 5.53 & 5.51 & 4.61 & 3.40 & 3.25 \\
\hline $\mathrm{K}_{2} \mathrm{O}$ & 0.44 & 0.30 & 0.24 & 0.30 & 0.26 & 0.25 & 0.26 & 0.25 & 0.06 & 0.14 \\
\hline $\mathrm{P}_{2} \mathrm{O}_{5}$ & 0.23 & 0.22 & 0.15 & 0.13 & 0.24 & 0.17 & 0.26 & 0.32 & 0.03 & 0.05 \\
\hline LOI & 3.52 & 1.09 & 0.07 & 0.49 & 0.05 & 0.15 & 0.30 & 0.50 & 0.59 & 1.02 \\
\hline total & 98.80 & 99.37 & 96.99 & 98.00 & 99.65 & 97.48 & 99.56 & 98.79 & 100.16 & 98.11 \\
\hline \multicolumn{11}{|c|}{ trace elements (ppm) } \\
\hline $\mathrm{Cu}$ & 4.2 & 0.4 & 59.3 & 2.1 & 0.6 & bdl & bdl & bdl & 1.9 & 0.4 \\
\hline $\mathrm{Li}$ & 2.6 & 1.2 & 3.2 & 1.5 & 3.1 & 2.4 & 2.4 & 4.6 & 0.5 & 1.5 \\
\hline $\mathrm{Cr}$ & 9.6 & 6.9 & 8.6 & 7.4 & 7.9 & 6.7 & 5.8 & 5.0 & 4.9 & 9.9 \\
\hline Co & 20 & 6.6 & 6.9 & 3.5 & 8.3 & 6.1 & 7.3 & 9.7 & 2.8 & 2.2 \\
\hline $\mathrm{Ni}$ & 1.1 & 0.6 & 21.7 & 0.7 & 0.7 & 0.7 & 0.6 & 1 & 4.3 & 2.9 \\
\hline $\mathrm{Zn}$ & 67.9 & 33.1 & 61.1 & 35.2 & 83.1 & 61.3 & 49.2 & 88.3 & 79.2 & 0.6 \\
\hline $\mathrm{Ga}$ & 19.5 & 24.8 & 27.5 & 29.8 & 26.7 & 25.4 & 23.3 & 23.3 & 14.2 & 14.6 \\
\hline $\mathrm{Ge}$ & 2.2 & 1.7 & 2.1 & 1.7 & 2.3 & 1.9 & 1.8 & 2.1 & 1.0 & 1.5 \\
\hline $\mathrm{Se}$ & 0.5 & 1.8 & 2.6 & 1.7 & 2.2 & 1.7 & 1.5 & 2.1 & 0.5 & 0.4 \\
\hline $\mathrm{Rb}$ & 0.7 & 1.2 & 2.1 & 1.4 & 2.2 & 1.9 & 0.8 & 3.5 & bdl & 1.0 \\
\hline $\mathrm{Sr}$ & 113 & 80.2 & 114 & 108 & 113 & 105 & 75.1 & 108 & 149 & 144 \\
\hline Y & 33.1 & 90.3 & 88 & 90.5 & 91.9 & 85 & 55.3 & 79.1 & 38.5 & 27.7 \\
\hline $\mathrm{Zr}$ & 117 & 363 & 425.0 & 425.0 & 396.0 & 370.0 & 271.0 & 387.0 & 45.0 & 35.0 \\
\hline $\mathrm{Nb}$ & 5.6 & 17.2 & 20.9 & 11.0 & 24.1 & 17.8 & 16.3 & 14.3 & 0.2 & 0.1 \\
\hline Cs & 0.62 & 0.65 & 0.66 & 0.66 & 0.64 & 0.64 & 0.56 & 0.64 & 0.62 & 0.65 \\
\hline $\mathrm{Ba}$ & 38 & 91 & 101.0 & 91.0 & 126.0 & 122.0 & 119.0 & 84.0 & 54.0 & 16.0 \\
\hline La & 4.19 & 15.8 & 17.20 & 16.60 & 22.40 & 16.40 & 13.40 & 22.40 & 1.72 & 1.31 \\
\hline $\mathrm{Ce}$ & 12.20 & 42.3 & 45.30 & 45.40 & 59.50 & 44.50 & 36.60 & 54.80 & 4.49 & 3.39 \\
\hline $\mathrm{Pr}$ & 1.99 & 6.5 & 6.72 & 6.92 & 8.76 & 6.64 & 5.63 & 7.72 & 0.81 & 0.64 \\
\hline $\mathrm{Nd}$ & 11.7 & 34 & 35.30 & 36.40 & 44.70 & 35.60 & 30.10 & 39.30 & 5.39 & 4.36 \\
\hline $\mathrm{Sm}$ & 4.5 & 11.00 & 11.60 & 12.10 & 13.80 & 11.70 & 10.00 & 12.20 & 2.76 & 2.15 \\
\hline $\mathrm{Eu}$ & 2.13 & 3.44 & 3.78 & 4.10 & 4.06 & 3.92 & 3.29 & 3.71 & 0.77 & 0.82 \\
\hline $\mathrm{Gd}$ & 5.47 & 14 & 14.00 & 15.30 & 15.90 & 14.50 & 12.60 & 14.40 & 4.18 & 3.37 \\
\hline $\mathrm{Tb}$ & 1.02 & 2.52 & 2.63 & 2.81 & 2.82 & 2.60 & 2.24 & 2.64 & 0.86 & 0.69 \\
\hline Dy & 6.74 & 16.7 & 17.20 & 18.10 & 17.90 & 16.60 & 14.50 & 17.00 & 6.06 & 5.05 \\
\hline $\mathrm{Ho}$ & 1.42 & 3.55 & 3.57 & 3.79 & 3.72 & 3.45 & 3.00 & 3.53 & 1.35 & 1.09 \\
\hline Er & 4.14 & 10.3 & 10.9 & 11.4 & 11.1 & 10.1 & 8.7 & 10.4 & 4.2 & 3.3 \\
\hline $\mathrm{Tm}$ & 0.634 & 1.56 & 1.6 & 1.7 & 1.7 & 1.5 & 1.3 & 1.6 & 0.7 & 0.5 \\
\hline $\mathrm{Yb}$ & 4.2 & 10 & 10.7 & 10.6 & 10.8 & 9.6 & 8.5 & 10.1 & 4.6 & 3.5 \\
\hline $\mathrm{Lu}$ & 0.706 & 1.63 & 1.8 & 1.5 & 1.7 & 1.6 & 1.4 & 1.6 & 0.8 & 0.6 \\
\hline $\mathrm{Hf}$ & 3.4 & 9.9 & 11.6 & 11.8 & 10.7 & 10.3 & 7.3 & 10.4 & 1.9 & 1.1 \\
\hline $\mathrm{Ta}$ & 0.44 & 1.12 & 1.35 & 0.83 & 1.47 & 1.09 & 1.1 & 1.01 & bdl & bdl \\
\hline $\mathrm{Pb}$ & bdl & bdl & bdl & bdl & bdl & bdl & bdl & bdl & bdl & bdl \\
\hline Th & 0.6 & 1.51 & 1.87 & 1.86 & 1.84 & 1.7 & 1.76 & 1.77 & 0.17 & 0.13 \\
\hline$U$ & 0.17 & 0.53 & 0.75 & 0.68 & 0.65 & 0.62 & 0.51 & 0.63 & 0.14 & 0.14 \\
\hline Sc & 27 & 8 & 12 & 7 & 10 & 14 & 12 & 22 & 14 & 14 \\
\hline $\mathrm{Be}$ & 0.7 & 1.6 & 1.8 & 1.6 & 1.8 & 1.6 & 1.5 & 1.5 & 0.4 & 0.3 \\
\hline V & 38 & bdl & bdl & bdl & bdl & bdl & bdl & bdl & 13 & 11 \\
\hline
\end{tabular}

Table 1 Whattam et al. (2016) 
Table 2

U-Th SHRIMP analyses of zircons from Nicoya plagiogranites

\begin{tabular}{|c|c|c|c|c|c|c|c|c|c|c|c|c|}
\hline Sample No. & Spot No. & $206 \mathrm{~Pb}^{\mathrm{C}} \%$ & Uppm & Th ppm & $\mathrm{Th} / \mathrm{U}$ & ${ }^{232} \mathrm{Th} /{ }^{238} \mathrm{U}$ & $\begin{array}{c}(1) \\
{ }^{207} \mathrm{~Pb}^{\star 2} /{ }^{235} \mathrm{U}\end{array}$ & $\pm \%$ & $\begin{array}{c}\text { (1) } \\
{ }^{206} \mathrm{~Pb}^{*} / 238 \mathrm{U}\end{array}$ & $\pm \%$ & $\begin{array}{c}\text { error } \\
\text { corrected }\end{array}$ & $\begin{array}{c}(2) \\
{ }^{206} \mathrm{~Pb} /{ }^{238} \mathrm{U} \\
\text { age }\end{array}$ \\
\hline $1-23-11-10$ & 123_1.1 & 19.13 & 179 & 143 & 0.80 & 0.83 & 0.109 & 80 & 0.01485 & 6.7 & 0.5 & $94.4 \pm 6$ \\
\hline $1-23-11-10$ & 123_2.1 & 33.45 & 88 & 35 & 0.39 & 0.41 & 0.127 & 89 & 0.01355 & 8.7 & 0.6 & $84.5 \pm 7$ \\
\hline $1-23-11-10$ & 123_3.1 & 16.94 & 191 & 139 & 0.73 & 0.75 & 0.092 & 66 & 0.01363 & 5.0 & 0.8 & $87.1 \pm 3$ \\
\hline $1-23-11-10$ & $123 \_4.1$ & 32.18 & 79 & 28 & 0.36 & 0.37 & 0.116 & 97 & 0.01360 & 12.3 & 0.6 & $85.5 \pm 8$ \\
\hline $1-23-11-10$ & 123_5.1 & 29.12 & 93 & 46 & 0.49 & 0.50 & 0.115 & 100 & 0.01438 & 9.4 & 0.6 & $90.9 \pm 8$ \\
\hline $1-23-11-10$ & 123_6.1 & 28.14 & 81 & 37 & 0.46 & 0.47 & 0.130 & 81 & 0.01378 & 8.0 & 0.6 & $85.9 \pm 7$ \\
\hline $1-23-11-10$ & 123_8.1 & 14.88 & 184 & 80 & 0.43 & 0.45 & 0.084 & 61 & 0.01400 & 4.3 & 0.5 & $90.1 \pm 4$ \\
\hline $1-23-11-10$ & 123_9.1 & 18.02 & 175 & 114 & 0.65 & 0.67 & 0.104 & 65 & 0.01387 & 5.4 & 0.5 & $88.1 \pm 4$ \\
\hline $1-23-11-10$ & 123_10.1 & 6.32 & 716 & 500 & 0.70 & 0.72 & 0.103 & 24 & 0.01392 & 1.8 & 0.7 & $88.4 \pm 1$ \\
\hline $1-23-11-10$ & 123_11.1 & 23.10 & 130 & 67 & 0.52 & 0.54 & 0.085 & 113 & 0.01355 & 8.0 & 0.7 & $87.0 \pm 6$ \\
\hline $1-23-11-10$ & 123_12.1 & 26.03 & 124 & 75 & 0.61 & 0.63 & 0.121 & 80 & 0.01418 & 7.5 & 0.6 & $89.2 \pm 6$ \\
\hline $1-23-11-10$ & 123_13.1 & 12.24 & 195 & 438 & 2.25 & 2.32 & 0.115 & 190 & 0.01411 & 3.1 & 0.3 & $89.0 \pm 6$ \\
\hline
\end{tabular}

\begin{tabular}{|c|c|c|c|c|c|c|c|c|c|c|c|c|}
\hline Sample No. & Spot No. & ${ }^{206} \mathrm{~Pb}^{\mathrm{c}} \%$ & U ppm & Th ppm & $\mathrm{Th} / \mathrm{U}$ & ${ }^{232} \mathrm{Th} /{ }^{238} \mathrm{U}$ & $\begin{array}{c}(1) \\
{ }^{207} \mathrm{~Pb}^{\star 2} /{ }^{235} \mathrm{U}\end{array}$ & $\pm \%$ & $\begin{array}{c}(1) \\
{ }^{206} \mathrm{~Pb}^{\star} /{ }^{238} \mathrm{U}\end{array}$ & $\pm \%$ & $\begin{array}{c}\text { error } \\
\text { corrected }\end{array}$ & $\begin{array}{c}\text { (2) } \\
{ }^{206} \mathrm{~Pb} /{ }^{238} \mathrm{U} \\
\text { age }\end{array}$ \\
\hline $2-23-11-10$ & 223_1.1 & 1.95 & 481 & 325 & 0.68 & 0.70 & 0.095 & 9 & 0.01390 & 1.4 & 0.3 & $88.7 \pm 1$ \\
\hline $2-23-11-10$ & 223_2.1 & 7.88 & 233 & 93 & 0.40 & 0.41 & 0.066 & 37 & 0.01387 & 2.5 & 0.6 & $90.3 \pm 2$ \\
\hline $2-23-11-10$ & 223_2.2 & 7.06 & 335 & 157 & 0.47 & 0.48 & 0.081 & 41 & 0.01360 & 2.1 & 0.6 & $87.5 \pm 2$ \\
\hline $2-23-11-10$ & 223_1.2 & 1.12 & 583 & 395 & 0.68 & 0.70 & 0.078 & 8 & 0.01302 & 5.8 & 0.5 & $83.8 \pm 4$ \\
\hline
\end{tabular}

\begin{tabular}{|c|c|c|c|c|c|c|c|c|c|c|c|c|}
\hline Sample No. & Spot No. & ${ }^{206} \mathrm{~Pb}^{\mathrm{c}} \%$ & U ppm & Th ppm & Th/U & ${ }^{232} \mathrm{Th} /{ }^{238} \mathrm{U}$ & $\begin{array}{c}(1) \\
{ }^{207} \mathrm{~Pb}^{\star 2} /{ }^{235} \mathrm{U}\end{array}$ & $\pm \%$ & $\begin{array}{c}(1) \\
{ }^{206} \mathrm{~Pb}^{*} / 238 \mathrm{U}\end{array}$ & $\pm \%$ & $\begin{array}{c}\text { error } \\
\text { corrected }\end{array}$ & $\begin{array}{c}{ }^{(2)} \\
{ }^{206} \mathrm{~Pb} /{ }^{238} \mathrm{U} \\
\text { age }\end{array}$ \\
\hline $3-23-11-10$ & 323_1.1 & 30.24 & 96 & 49 & 0.51 & 0.52 & 0.078 & 104 & 0.01169 & 6.8 & 0.7 & $78.8 \pm 5$ \\
\hline $3-23-11-10$ & 323_2.1 & 8.36 & 273 & 174 & 0.64 & 0.66 & 0.124 & 25 & 0.01352 & 6.0 & 0.2 & $84.5 \pm 5$ \\
\hline $3-23-11-10$ & 323_5.1 & 2.07 & 612 & 862 & 1.41 & 1.45 & 0.101 & 24 & 0.01433 & 1.7 & 0.3 & $91.4 \pm 1$ \\
\hline $3-23-11-10$ & $323 \_6.1$ & 7.54 & 273 & 140 & 0.51 & 0.53 & 0.097 & 27 & 0.01413 & 1.5 & 0.4 & $90.2 \pm 2$ \\
\hline $3-23-11-10$ & 323_7.1 & 17.63 & 188 & 117 & 0.62 & 0.64 & 0.122 & 55 & 0.01402 & 5.7 & 0.6 & $88.0 \pm 5$ \\
\hline $3-23-11-10$ & 323_9.1 & 5.81 & 379 & 450 & 1.19 & 1.22 & 0.102 & 43 & 0.01410 & 2.7 & 0.6 & $89.7 \pm 2$ \\
\hline $3-23-11-10$ & 323_10.1 & 3.05 & 561 & 347 & 0.62 & 0.64 & 0.092 & 12 & 0.01405 & 0.9 & 0.3 & $90.0 \pm 0.9$ \\
\hline $3-23-11-10$ & $323 \_11.1$ & 21.00 & 152 & 59 & 0.39 & 0.40 & 0.091 & 91 & 0.01296 & 6.2 & 0.6 & $87.2 \pm 5$ \\
\hline $3-23-11-10$ & 323_12.1 & 5.29 & 312 & 316 & 1.01 & 1.05 & 0.091 & 39 & 0.01418 & 1.9 & 0.7 & $90.9 \pm 1$ \\
\hline $3-23-11-10$ & $323 \_14.1$ & 9.63 & 272 & 139 & 0.51 & 0.53 & 0.105 & 40 & 0.01354 & 4.2 & 0.6 & $85.8 \pm 3$ \\
\hline $3-23-11-10$ & $323-15.1$ & 13.37 & 122 & 74 & 0.61 & 0.63 & 0.089 & 78 & 0.01376 & 5.7 & 0.5 & $88.2 \pm 5$ \\
\hline $3-23-11-10$ & $323 \_16.1$ & 15.39 & 202 & 87 & 0.43 & 0.45 & 0.090 & 71 & 0.01329 & 4.8 & 0.6 & $84.9 \pm 4$ \\
\hline $3-23-11-10$ & $323 \_17.1$ & 4.17 & 337 & 193 & 0.57 & 0.59 & 0.064 & 13 & 0.01347 & 1.6 & 0.8 & $87.7 \pm 0.8$ \\
\hline $3-23-11-10$ & $323-18.1$ & 20.20 & 175 & 88 & 0.50 & 0.52 & 0.129 & 62 & 0.01381 & 7.6 & 0.6 & $86.2 \pm 6$ \\
\hline $3-23-11-10$ & 323_20.1 & 19.68 & 87 & 48 & 0.55 & 0.57 & 0.103 & 58 & 0.01344 & 5.6 & 0.5 & $85.2 \pm 4$ \\
\hline $3-23-11-10$ & $323-21.1$ & 5.96 & 459 & 337 & 0.73 & 0.76 & 0.073 & 49 & 0.01275 & 7.1 & 0.5 & $82.3 \pm 5$ \\
\hline
\end{tabular}

\begin{tabular}{|c|c|c|c|c|c|c|c|c|c|c|c|c|}
\hline Sample No. & Spot No. & ${ }^{206} \mathrm{~Pb}^{\mathrm{c}} \%$ & U ppm & Th ppm & $\mathrm{Th} / \mathrm{U}$ & ${ }^{232} \mathrm{Th} / 238 \mathrm{U}$ & $\begin{array}{c}(1) \\
{ }^{207} \mathrm{~Pb}^{\star / / 35} \mathrm{U}\end{array}$ & $\pm \%$ & $\begin{array}{c}(1) \\
{ }^{206} \mathrm{~Pb}^{*} /{ }^{238} \mathrm{U}\end{array}$ & $\pm \%$ & $\begin{array}{c}\text { error } \\
\text { corrected }\end{array}$ & $\begin{array}{c}{ }^{(2)} \\
{ }^{206} \mathrm{~Pb} /{ }^{238} \mathrm{U} \\
\text { age }\end{array}$ \\
\hline $4-23-11-10$ & $423 \_1.1$ & 17.36 & 344 & 301 & 0.87 & 0.90 & 0.076 & 63 & 0.01236 & 13.1 & 0.3 & $79.5 \pm 7$ \\
\hline $4-23-11-10$ & 423_2.1 & 11.75 & 583 & 569 & 0.98 & 1.01 & 0.092 & 21 & 0.01341 & 2.5 & 0.3 & $85.6 \pm 2$ \\
\hline $4-23-11-10$ & 423_3.1 & 9.95 & 471 & 584 & 1.24 & 1.28 & 0.041 & 103 & 0.01271 & 3.0 & 0.5 & $83.9 \pm 2$ \\
\hline $4-23-11-10$ & 423_4.1 & 4.42 & 722 & 834 & 1.16 & 1.19 & 0.093 & 37 & 0.01396 & 1.7 & 0.8 & $89.3 \pm 1$ \\
\hline $4-23-11-10$ & $423 \_6.1$ & 8.29 & 705 & 1070 & 1.52 & 1.57 & 0.059 & 88 & 0.01294 & 4.0 & 0.4 & $84.4 \pm 2$ \\
\hline $4-23-11-10$ & 423_7.1 & 4.68 & 748 & 1295 & 1.73 & 1.79 & 0.108 & 43 & 0.01369 & 5.9 & 0.2 & $86.6 \pm 4$ \\
\hline $4-23-11-10$ & $423 \_8.1$ & 30.13 & 1008 & 1363 & 1.35 & 1.40 & 0.031 & 182 & 0.01389 & 2.4 & 0.9 & $92.4 \pm 0.7$ \\
\hline $4-23-11-10$ & 423_9.1 & 14.11 & 394 & 299 & 0.76 & 0.78 & 0.076 & 37 & 0.01245 & 11.5 & 0.3 & $80.1 \pm 7$ \\
\hline $4-23-11-10$ & 423_10.1 & 4.12 & 1054 & 1409 & 1.34 & 1.38 & 0.070 & 73 & 0.01384 & 2.4 & 0.7 & $89.8 \pm 1$ \\
\hline $4-23-11-10$ & $423 \_11.1$ & 14.12 & 329 & 302 & 0.92 & 0.95 & 0.047 & 182 & 0.01238 & 5.3 & 0.7 & $81.3 \pm 4$ \\
\hline $4-23-11-10$ & 423_13.1 & 6.28 & 519 & 568 & 1.09 & 1.13 & 0.052 & 51 & 0.01238 & 3.1 & 0.2 & $81.1 \pm 2$ \\
\hline $4-23-11-10$ & $423 \_15.1$ & 39.34 & 588 & 517 & 0.88 & 0.91 & 0.060 & 144 & 0.01332 & 14.6 & 0.5 & $86.9 \pm 7$ \\
\hline $4-23-11-10$ & 423_16.1 & 12.09 & 469 & 662 & 1.41 & 1.46 & 0.105 & 68 & 0.01298 & 4.7 & 0.5 & $82.0 \pm 3$ \\
\hline $4-23-11-10$ & 423_18.1 & 20.52 & 740 & 980 & 1.32 & 1.37 & 0.074 & 159 & 0.01290 & 6.3 & 0.7 & $83.2 \pm 3$ \\
\hline $4-23-11-10$ & $423 \_19.1$ & 13.49 & 429 & 520 & 1.21 & 1.25 & 0.094 & 43 & 0.01358 & 3.8 & 0.2 & $86.7 \pm 3$ \\
\hline Sample No. & Spot No. & ${ }^{206} \mathrm{~Pb}^{\mathrm{c}} \%$ & U ppm & Th ppm & $\mathrm{Th} / \mathrm{U}$ & ${ }^{232} \mathrm{Th} /{ }^{238} \mathrm{U}$ & $\begin{array}{c}(1) \\
{ }^{207} \mathrm{~Pb}^{\star} /{ }^{235} \mathrm{U}\end{array}$ & $\pm \%$ & $\begin{array}{c}(1) \\
{ }^{206} \mathrm{~Pb}^{*} /{ }^{238} \mathrm{U}\end{array}$ & $\pm \%$ & $\begin{array}{c}\text { error } \\
\text { corrected }\end{array}$ & $\begin{array}{c}{ }^{(2)} \\
{ }^{206} \mathrm{~Pb} /{ }^{238} \mathrm{U} \\
\text { age }\end{array}$ \\
\hline $\mathrm{CN}-14-7-1$ & CN_1.1 & 7.42 & 546 & 807 & 1.48 & 1.53 & 0.108 & 85 & 0.01441 & 6.7 & 0.4 & $91.5 \pm 4$ \\
\hline $\mathrm{CN}-14-7-1$ & CN_2.1 & 6.36 & 366 & 320 & 0.88 & 0.91 & 0.081 & 42 & 0.01310 & 4.3 & 0.5 & $84.2 \pm 3$ \\
\hline $\mathrm{CN}-14-7-1$ & CN_3.1 & 9.65 & 317 & 368 & 1.16 & 1.20 & 0.103 & 65 & 0.01440 & 3.4 & 0.7 & $91.7 \pm 2$ \\
\hline $\mathrm{CN}-14-7-1$ & CN_4.1 & 9.49 & 340 & 451 & 1.33 & 1.37 & 0.076 & 54 & 0.01340 & 2.8 & 0.2 & $86.5 \pm 2$ \\
\hline $\mathrm{CN}-14-7-1$ & CN_0.1 & 0.81 & 1029 & 1267 & 1.23 & 1.27 & 0.079 & 14 & 0.01406 & 1.4 & 0.4 & $90.8 \pm 1$ \\
\hline $\mathrm{CN}-14-7-1$ & CN_1.3 & 5.21 & 527 & 721 & 1.37 & 1.41 & 0.144 & 19 & 0.01488 & 1.2 & 0.4 & $92.6 \pm 1$ \\
\hline $\mathrm{CN}-14-7-1$ & CN-4.2 & 17.00 & 110 & 85 & 0.77 & 0.80 & 0.085 & 98 & 0.01360 & 8.5 & 0.4 & $87.3 \pm 6$ \\
\hline $\mathrm{CN}-14-7-1$ & CN_6.1 & 9.48 & 272 & 104 & 0.38 & 0.39 & 0.107 & 35 & 0.01471 & 2.5 & 0.5 & $93.6 \pm 3$ \\
\hline
\end{tabular}

Errors are 1-sigma; $\mathrm{Pb}^{\mathrm{c}}$ and $\mathrm{Pb}^{*}$ indicate the common and radiogenic portions, respectively.

Error in Standard calibration was $0.14 \%$ (not included in above errors but required when comparing data from different mounts).

(1) Common $\mathrm{Pb}$ corrected by assuming ${ }^{206} \mathrm{~Pb} /{ }^{238} \mathrm{U}-{ }^{208} \mathrm{~Pb} /{ }^{232} \mathrm{Th}$ age-concordance.

(2) Common $\mathrm{Pb}$ corrected by assuming ${ }^{206} \mathrm{~Pb} /{ }^{238} \mathrm{U}-{ }^{207} \mathrm{~Pb} /{ }^{235} \mathrm{U}$ age-concordance. 
Table 3

U-Th SHRIMP analyses of zircons from Santa Elena plagiogranites

\begin{tabular}{|c|c|c|c|c|c|c|c|c|c|c|c|c|}
\hline Sample No. & Spot No. & ${ }^{206} \mathrm{~Pb}^{\mathrm{c}} \%$ & U ppm & Th ppm & $\mathrm{Th} / \mathrm{U}$ & ${ }^{232} \mathrm{Th} /{ }^{238} \mathrm{U}$ & $\begin{array}{c}(1) \\
{ }^{207} \mathrm{~Pb}^{\star / 235} \mathrm{U}\end{array}$ & $\pm \%$ & $\begin{array}{c}(1) \\
{ }^{206} \mathrm{~Pb}^{\star} /{ }^{238} \mathrm{U}\end{array}$ & $\pm \%$ & $\begin{array}{c}\text { error } \\
\text { corrected }\end{array}$ & $\begin{array}{c}(2) \\
{ }^{206} \mathrm{~Pb} /{ }^{238} \mathrm{U} \\
\text { age }\end{array}$ \\
\hline SE-040611-9 & SE_1.1 & 18.11 & 122 & 40 & 0.33 & 0.34 & 0.150 & 64 & 0.01961 & 4.2 & 0.6 & $124 \pm 6$ \\
\hline SE-040611-9 & SE_3.1 & 2.24 & 114 & 57 & 0.50 & 0.52 & 0.127 & 7 & 0.01955 & 2.1 & 0.4 & $125 \pm 2$ \\
\hline SE-040611-9 & SE_4.1 & 11.94 & 78 & 24 & 0.30 & 0.31 & 0.061 & 86 & 0.02162 & 3.4 & 0.7 & $143 \pm 4$ \\
\hline SE-040611-9 & SE_5.1 & 23.36 & 66 & 18 & 0.27 & 0.28 & 0.116 & 61 & 0.01886 & 9.9 & 0.2 & $121 \pm 9$ \\
\hline SE-040611-9 & SE_6.1 & 10.69 & 122 & 51 & 0.42 & 0.43 & 0.123 & 64 & 0.01905 & 4.3 & 0.5 & $122 \pm 6$ \\
\hline SE-040611-9 & SE_7.1 & 13.38 & 75 & 22 & 0.30 & 0.31 & 0.137 & 64 & 0.02032 & 5.1 & 0.6 & $130 \pm 6$ \\
\hline SE-040611-9 & SE_8.1 & 15.39 & 176 & 66 & 0.37 & 0.39 & 0.077 & 102 & 0.02382 & 3.4 & 0.7 & $157 \pm 5$ \\
\hline SE-040611-9 & SE_9.1 & 2.53 & 357 & 202 & 0.57 & 0.59 & 0.137 & 18 & 0.02007 & 1.3 & 0.6 & $128 \pm 2$ \\
\hline SE-040611-9 & SE_10.1 & 8.99 & 230 & 56 & 0.24 & 0.25 & 0.148 & 25 & 0.02092 & 1.3 & 0.2 & $133 \pm 3$ \\
\hline SE-040611-9 & SE_11.1 & 15.16 & 58 & 13 & 0.23 & 0.24 & 0.193 & 53 & 0.02022 & 2.5 & 0.2 & $126 \pm 6$ \\
\hline SE-040611-9 & SE_12.1 & 28.68 & 71 & 18 & 0.26 & 0.26 & 0.343 & 35 & 0.02068 & 9.1 & 0.2 & $120 \pm 10$ \\
\hline SE-040611-9 & SE_13.1 & 18.72 & 88 & 31 & 0.35 & 0.36 & 0.115 & 146 & 0.01849 & 7.0 & 0.6 & $119 \pm 10$ \\
\hline SE-040611-9 & SE_14.1 & 19.62 & 81 & 30 & 0.38 & 0.39 & 0.116 & 72 & 0.01899 & 6.5 & 0.6 & $122 \pm 7$ \\
\hline SE-040611-9 & SE_15.1 & 11.29 & 57 & 15 & 0.27 & 0.28 & 0.178 & 41 & 0.01969 & 4.0 & 0.7 & $123 \pm 5$ \\
\hline SE-040611-9 & SE_16.1 & 5.60 & 316 & 186 & 0.59 & 0.61 & 0.144 & 23 & 0.01964 & 1.6 & 0.6 & $125 \pm 2$ \\
\hline SE-040611-9 & SE_17.1 & 31.86 & 65 & 24 & 0.36 & 0.38 & 0.235 & 65 & 0.01892 & 11.3 & 0.6 & $115 \pm 11$ \\
\hline SE-040611-9 & SE_17.2 & 9.87 & 155 & 61 & 0.39 & 0.40 & 0.140 & 43 & 0.01975 & 2.1 & 0.4 & $126 \pm 4$ \\
\hline SE-040611-9 & SE_18.1 & 6.17 & 270 & 88 & 0.32 & 0.34 & 0.120 & 35 & 0.01895 & 2.3 & 0.7 & $121 \pm 3$ \\
\hline SE-040611-9 & SE_19.1 & 6.01 & 148 & 45 & 0.30 & 0.31 & 0.140 & 26 & 0.01944 & 2.9 & 0.3 & $124 \pm 4$ \\
\hline SE-040611-9 & SE_20.1 & 7.01 & 148 & 60 & 0.41 & 0.42 & 0.122 & 36 & 0.01922 & 2.8 & 0.5 & $123 \pm 3$ \\
\hline SE-040611-9 & SE_22.1 & 8.69 & 281 & 126 & 0.45 & 0.46 & 0.116 & 37 & 0.01778 & 4.4 & 0.4 & $114 \pm 4$ \\
\hline
\end{tabular}

Errors are 1-sigma; $\mathrm{Pb}^{\mathrm{c}}$ and $\mathrm{Pb}^{*}$ indicate the common and radiogenic portions, respectively.

Error in Standard calibration was $0.14 \%$ (not included in above errors but required when comparing data from different mounts).

(1) Common $\mathrm{Pb}$ corrected by assuming ${ }^{206} \mathrm{~Pb} /{ }^{238} \mathrm{U}-{ }^{208} \mathrm{~Pb} /{ }^{232} \mathrm{Th}$ age-concordance.

(2) Common $\mathrm{Pb}$ corrected by assuming ${ }^{206} \mathrm{~Pb} /{ }^{238} \mathrm{U}-{ }^{207} \mathrm{~Pb} /{ }^{235} \mathrm{U}$ age-concordance.

Table 3 Whattam et al. (2016) 